\title{
FLORA DA SERRA DO CIPÓ, MINAS GERAIS: MORACEAE ${ }^{1}$
}

\author{
EUDER GLENDES ANDRADE MARTINS* \& JOSÉ RUBENS PIRANI
}

\author{
Departamento de Botânica, Instituto de Biociências, Universidade de São Paulo, Rua do Matão, 277, \\ Cidade Universitária, 05508-900 - São Paulo, SP, Brasil. \\ *Endereço atual: Centro de Capacitação e Pesquisa em Meio Ambiente - CEPEMA, Universidade de São Paulo, Rodovia Cônego \\ Domenico Rangoni km 214, Zona Industrial, 11573-000 - Cubatão, SP, Brasil. Autor para correspondência: euder@usp.br.
}

\begin{abstract}
Flora of Serra do Cipó, Minas Gerais: Moraceae). This treatment of the family Moraceae is part of the "Flora of the Serra do Cipó, Minas Gerais, Brazil" project. In that area, the family is represented by Brosimum (B. gaudichaudii), Dorstenia (D. brasiliensis), Ficus (5spp.), Helicostylis (H. tomentosa), Maclura (M. tinctoria), Pseudolmedia (P. laevigata), and Sorocea (S. guilleminiana). Keys of the genera, descriptions, and illustrations, as well as comments on the geographic distribution, phenology, and variability of the species are presented.
\end{abstract}

Resumo- (Flora da Serra do Cipó, Minas Gerais: Moraceae). Este tratamento da família Moraceae é parte do levantamento da Flora da Serra do Cipó, Minas Gerais, Brasil. A família está representada na área por Brosimum (B. Gaudichaudii), Dorstenia (D. brasiliensis), Ficus (5spp.), Helicostylis (H. tomentosa), Maclura (M. tinctoria), Pseudolmedia (P. laevigata) e Sorocea (S. guilleminiana). São apresentadas chaves para gêneros, descrições e ilustrações das mesmas, além de comentários sobre sua distribuição geográfica, fenologia e variabilidade.

Key words: Moraceae, taxonomy, Serra do Cipó, Brazil, floristics, campo rupestre vegetation.

\section{Moraceae}

Árvores, arbustos, ervas, às vezes lianas lenhosas, epífitas ou hemiepífitas, latescentes. Folhas simples, raramente compostas, persistentes ou não, alternas, espiraladas ou dísticas, raramente opostas ou verticiladas a rosuladas; lâmina subcoriácea a coriácea, às vezes cartácea a raramente membranácea, basifixa, inteira, às vezes lobada, crenada, denteada ou serreada; venação craspedódroma ou camptódroma, raramente actinódroma; pecíolo presente; estípulas intrapeciolares, raramente interpeciolares, reduzidas a amplas, livres ou conatas, amplexicaules ou não, decíduas ou persistentes, deixando cicatrizes anulares. Inflorescências bissexuadas ou unissexuadas (plantas monóicas, androdióicas ou ginodióicas), axilares ou caulifloras, unifloras ou multifloras, bracteadas ou não, cimeiras ou racemos, espigas, pseudo-umbelas, capítulos globosos, fechados ou achatados, sendo dos tipos especiais cenanto (em Dorstenia) e sicônio (em Ficus). Flores actinomorfas, aclamídeas ou monoclamídeas; perianto simples, tépalas livres ou fusionadas, valvadas ou imbricadas, persistentes ou decíduas; flores estaminadas: (2-)4(5)-tépalas; (1-)3(4) estames, isostêmones, às vezes oligostêmones, oposititépalos, curvos ou retos no botão, anteras 2 , rimosas, filetes livres ou conatos; pistilódio reduzido ou ausente; flores pistiladas: 0-4-tépalas, persistentes, carnosas na maturação; estilete indiviso ou bifurcado, estigma 1 ou 2; ovário súpero, semiínfero ou ínfero, às vezes adnato ao perianto, 1-2-carpelar, unilocular; óvulo ereto ou pêndulo, anátropo, hemítropo ou campilótropo, subapical, bitegumentado, crassinucelado; estaminódio ausente. Frutos simples ou compostos, drupáceos ou aquênios, às vezes formando sicocarpos ou sincarpos, raramente secos, geralmente envoltos por perianto expandido, suculento e/ou imerso em um receptáculo carnoso; sementes amplas, endosperma presente ou ausente; embrião curvo ou reto, cotilédones espessos, planos ou dobrados, geralmente desiguais.

Moraceae é uma família de ampla distribuição geográfica, mas concentrada nas regiões tropicais e subtropicais. Compreende aproximadamente 1050 a 1100 espécies distribuídas em ca. 37 gêneros (Berg 2001, Martins et al. 2007). Na região Neotropical, a família está representada por 19 gêneros e aproximadamente 270 espécies, sendo mais abundante na região central da América do Sul (Berg \& Simonis 2000, Berg \& Villavicencio 2004). No Brasil, é representada por cerca de $30 \%$ dos seus gêneros, concentrados principalmente na Amazônia (Berg 2001, Datwyler \& Weiblein 2004). No presente trabalho, não foram incluídos alguns gêneros tradicionalmente considerados em Moraceae, como Cecropia Loefl., Coussapoa Aubl. e Pourouma Aubl., uma vez que atualmente são tratados na família Urticaceae (e.g. Stevens 2001).

\footnotetext{
${ }^{1}$ Trabalho preparado segundo o planejamento apresentado em Giulietti et al. (1987). Parte da Dissertação de Mestrado do primeiro autor, apresentada ao Instituto de Biociências, Universidade de São Paulo.
} 
As flores unissexuadas e reduzidas, associadas a limites taxonômicos confusos e ampla variação morfológica de muitas espécies tornam a sistemática de Moraceae complexa, exigindo grande esforço de campo e mais revisões taxonômicas (Berg 1978, 2001; Romaniuc-Neto 1998; Carauta et al. 2002). Tais dificuldades podem ter contribuído para o atual estado precário de conhecimento da família no Brasil (Castro \& Rapini 2006).

Bibliografia básica - Miquel (1847, 1853), Trécul (1847), Corner (1962), Berg (1972, 2001), Carauta (1989), Romaniuc-Neto, S. (1998), Berg \& Simonis (2000), Carauta $\& \operatorname{Diaz}(2002 a)$.

\section{Chave para os gêneros}

1. Plantas herbáceas; inflorescências do tipo cenanto

2. Dorstenia

1'. Plantas lenhosas; inflorescências do tipo sicônio, racemo, espiga ou globoso- capitadas.

2. Estípulas amplexicaules; inflorescências bissexuadas.

3. Inflorescências urceoladas (sicônios), flores pistiladas numerosas; glândulas baselaminares ou acropeciolares na face abaxial da lâmina

3. Ficus

3'. Inflorescências espigas globosas, 1 raramente 2 flores pistiladas; glândulas ausentes na lâmina ............... 1. Brosimum

2'. Estípulas laterais, não amplexicaules (exceto em Pseudolmedia); inflorescências unissexuadas.

4. Plantas dióicas; venação semicraspedódroma ou broquidódroma; margem denteada ou espinudada; inflorescências racemosas, espigadas ou globoso-capitadas, multifloras.

5. Plantas armadas; estames 4 , curvos no botão; pistilódio presente

5'. Plantas inermes; estames 2-4, retos no botão; pistilódio geralmente ausente

7. Sorocea

4'. Plantas monóicas ou dióicas; venação broquidódroma; margem inteira, raro denticulada próximo ao ápice;

inflorescências discóide-capitadas, unifloras.

6. Inflorescências estaminadas sésseis, solitárias; pecíolo glabro a levemente pubérulo; face abaxial glabra a esparsamente pubérula 6. Pseudolmedia

6'. Inflorescências estaminadas pedunculadas, fasciculadas; pecíolo tomentoso a pubescente; face abaxial densamente tomentosa a pubescente, às vezes levemente hirtela 4. Helicostylis

\section{Brosimum Sw.}

Árvores ou arbustos, até $10 \mathrm{~m}$ alt.; ramos cilíndricos; látex alvo a amarelado. Folhas geralmente dísticas; lâmina inteira, membranácea a coriácea, às vezes cartácea, assimétrica, margem denteada a levemente repanda, glândulas ausentes; venação broquidódroma; pecíolo plano, levemente pubescente a glabro; estípulas livres ou conatas, às vezes totalmente amplexicaules, geralmente decíduas. Inflorescências bissexuadas, pedunculadas, globosas a subglobosas; brácteas interflorais presentes, peltadas, inicialmente cobrindo o receptáculo; flores estaminadas geralmente numerosas, livres, perianto desenvolvido, tépalas 2-4-lobadas ou partidas, livres ou conatas, às vezes reduzidas, raramente ausentes; estames $1-4$, retos no botão; anteras às vezes extrorsas; pistilódio ausente; flores pistiladas várias ou apenas uma, imersas no receptáculo; tépalas 1-5(-7), às vezes ausentes, estilete e estigma sobressalentes ao receptáculo. Drupas globosas, raro múltiplo, sementes envoltos por endocarpo carnoso.

Brosimum compreende um total de 15 espécies distribuídas pela América tropical e subtropical, preferencialmente em cerrados ou savanas (Kubitzki et al. 1993, Berg \& Simonis 2000, Berg 2001).

1.1. Brosimum gaudichaudii Trécul, Ann. Sci. Nat., Bot., sér. 3, 8: 140. 1847.

Nomes vulgares: inharé, mamica-de-cachorra, mamicade-cadela, mamica-de-porco (MG, SP; Berg 1972, Crestana et al. 2006).
Fig. 1 A-E

Árvores ou arbustos, 4-7 m alt.; ramos folhosos 1-5 $\mathrm{mm}$ larg., pubescentes a hirtelos, às vezes levemente tomentosos; látex fosco, copioso. Lâmina foliar cartácea a subcoriácea ou coriácea, $(1,2-) 3,5-7,0(-9,0) \mathrm{cm}$ compr., $(1,0-$ )1,5-3,5(-4,5) cm larg., elíptica a oblonga ou lanceolada, levemente assimétrica, geralmente mais ampla acima da metade, ápice obtuso a agudo ou curto-acuminado, base aguda a obtusa ou levemente subcordada, margem inteira, às vezes denteada a denticulada, frequentemente revoluta; face adaxial esparso-pubescente a hirtela, indumento mais concentrado sobre as nervuras; face abaxial pubescente a hirtela ou levemente tomentosa; venação levemente proeminente a impressa na face adaxial, proeminente na face abaxial, nervuras secundárias 6-11 pares, terciárias reticuladas, às vezes reduzidas ou ausentes; pecíolo 0,3$1,0 \mathrm{~cm}$ compr., pubescente; estípulas $2-8 \mathrm{~mm}$ compr., pubescentes a tomentosas. Inflorescências pêndulas, globosas a hemisféricas, 2,0-4,5 mm compr., pedúnculo 1,2$3,3 \mathrm{~cm}$ compr., glabro a densamente pubescente; brácteas muitas, 0,3-1,8 mm compr., pubescentes, frequentemente tuberculadas no centro; flores estaminadas: várias, perianto ausente ou semelhante à bráctea; estame 1(2), circundado pelo perianto; filetes $0,2-0,7 \mathrm{~mm}$ compr., anteras $0,2-0,5 \mathrm{~mm}$ compr., 0,2-0,4 mm larg., levemente conduplicada, conectivo amplo; flor pistilada: 1, perianto reduzido ou ausente, estilete 0,7-1,5 mm compr., estigmas 0,6-1,0 mm compr. Fruto subgloboso, 1,0-1,8 cm diâm., amarelo a alaranjado na maturação; semente única, embrião invaginado. 


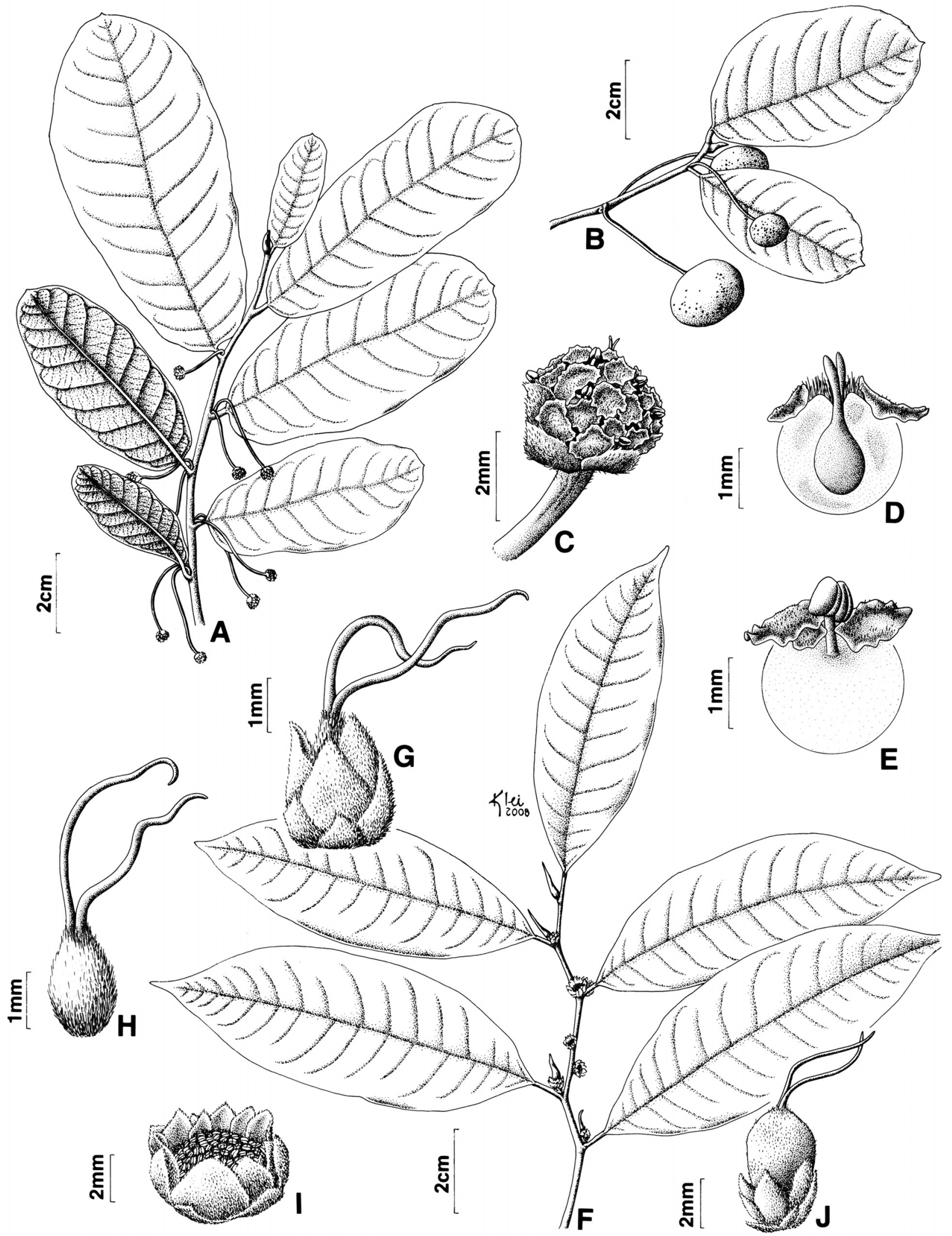

Fig. 1. A-E. Brosimum gaudichaudii. A. Ramo fértil. B. Ramo frutífero. C. Inflorescência bissexuada. D. Flor pistilada. E. Flor estaminada. F-J. Pseudolmedia laevigata. F. Ramo fértil. G. Brácteas da flor pistilada. H. Flor pistilada. I. Inflorescência estaminada. J. Fruto. A, C-E: Lombardi \& Toledo 454. B: Yamamoto \& Freitas 67. F-I: Martins et al. 66. J: Pirani CFSC 7598. 
Material examinado: Minas Gerais, Itambé do Mato Dentro, distrito de Santana do Rio Preto (Cabeça de Boi), propriedades do José Agostinho, 19²3'46.9'S 43024'07.4'W, M.F. Santos \& L.M. Borges 542, 15.VII.2007, st. (SPF). Jaboticatubas, Serra do Cipó, proximidades da sede do IBAMA, K. Yamamoto \& M.F. Freitas 67, 21.XI.2000, fr. (UEC); proximidades da sede do IBAMA, 19020'S 43037'W, alt. 600700 m, L.S. Kinoshita \& M.E. Alencar 367, 21.XI.2000, fr. (UEC). Santana do Riacho, distrito de Cardeal Mota, Serra do Cipó, trilha para as Cachoeiras dos Gaviões e da Farofa, 19020'35"S 43035'15"W, K. Yamamoto et al. 111, 27.IX.2002, fl. (UEC); Serra do Cipó, logo depois do rio Cipó, J.A. Lombardi \& F.R.N. Toledo 454, 20.X.1993, fl., fr. (BHCB, MBM).

Material adicional: Bahia, Barreiras, BR-242, km 774, em direção a Ibotirama, beira da estrada, $12^{\circ} 16^{\prime} 07^{\prime}$ 'S 44084'87'W, J. Paula-Souza et al. 940, 10.X.2007, fl. (SI, SPF); Chapada Diamantina, Rio de Contas, estrada de acesso ao Pico das Almas, 13031'05"S 41054'27'W, N. Roque et al. 970, 6.XII.2003, fr. (ALCB, SPF).

Brosimum gaudichaudii distribui-se principalmente na América tropical desde a Amazônia brasileira até a Bolívia e leste do Paraguai. No Brasil, distribui-se do nordeste da Bacia Amazônica, passando pelo cerrado, cerradão e áreas abertas do Brasil central ao leste, aqui crescendo em áreas degradadas, florestas secundárias e matas de transição (Berg 2001). Em Minas Gerais, é frequente no domínio atlântico do Vale do Jequitinhonha e Vale do Rio Doce e no domínio do cerrado na Cadeia do Espinhaço (Oliveira Filho 2006). Na Serra do Cipó, ocorre principalmente nos cerrados e campos rupestres e nos campos abertos ao longo das trilhas para as Cachoeiras dos Gaviões e da Farofa, no interior do Parque Nacional da Serra do Cipó.

Embora, em Brosimum, predominem espécies arbóreas, muitos exemplares de $B$. gaudichaudii são arvoretas ou mesmo arbustos de campos e cerrados. Seus indivíduos são facilmente identificados pelas inflorescências geralmente pêndulas e globosas, e pelas folhas cartáceas a coriáceas, com látex alvo abundante. No entanto, conforme observado por Berg (1972), a dimensão de suas folhas é muito variável, podendo o mesmo espécime apresentar folhas pequenas e grandes, sendo as pequenas freqüentemente achadas em ramos laterais curtos, próximas ao pedúnculo da inflorescência.

Floresce geralmente o ano todo, mas na Serra do Cipó são encontrados indivíduos florescendo principalmente em setembro e outubro, e frutificando em novembro a janeiro.

\section{Dorstenia L.}

Ervas até $0,8(-1,3) \mathrm{m}$ alt., rizomatosas, às vezes tuberosas; entrenós curtos ou alongados. Folhas espiraladas ou rosuladas; lâmina inteira ou lobada a partida, basifixa, margem frequentemente denteada a crenada; venação broquidódroma ou actinódroma; pecíolo levemente canaliculado, glabro a esparso-pubescente; estípulas membranáceas a coriáceas, laterais, geralmente persistentes. Cenanto bissexuado, solitário, axilar, pedunculado, discóide a orbicular, elíptico a arredondado ou quadrangular, margem inteira ou lobada, com verticilos de brácteas marginais, apêndices filiformes geralmente presentes; flores conatas; brácteas interflorais ausentes ou rudimentares; flores estaminadas: tépalas 2 ou 3, lobadas, geralmente livres, pediceladas, conatas ao perianto das flores pistiladas; estames 1 ou 2(-4), inflexos no botão, retos e exsertos posteriormente; pistilódio ocasionalmente presente; flores pistiladas: tépalas 2 ou 3, lobadas, tubulares, livres na parte apical, sésseis; ovário livre; estigma bífido, curtamente filiforme, às vezes ramos de comprimentos desiguais. Drupas deiscentes reunidas no receptáculo espessado do cenanto, exocarpo carnoso ou suculento, endocarpo verrucoso; semente pequena, testa delgada, endosperma presente.

Dorstenia apresenta distribuição pantropical, com aproximadamente 344 espécies concentradas principalmente na África. Ocorre desde o norte do México ao sul do Uruguai e Argentina, tendo sido registradas 46 espécies na América tropical (Berg \& Simonis 2000, Berg 2001). No Brasil, ocorrem aproximadamente 37 espécies (Carauta 1978, Carauta et al. 1996, Berg 2001, Carauta et al. 2002), habitando principalmente nas florestas amazônicas, no cerrado, na caatinga e nas diversas fisionomias da Mata Atlântica.

\subsection{Dorstenia brasiliensis Lam., Encycl. 2: 317. 1786.}

Nomes vulgares: caiapiá, carapiá, tarope (Carauta et al. 1996).

Fig. $2 \mathrm{~A}$

Erva, caule subterrâneo, cilíndrico, (1,0-)3,0-10,5 mm diâm., levemente tuberoso, glabro, entrenós curtos, odorífero. Folhas rosuladas, às vezes espiraladas; lâmina cartácea a levemente coriácea, (1,0-)2,5-6,3(-10,0) cm compr., (0,7)1,0-2,7(-4,0) cm larg., oblonga a elíptica ou obovada a lanceolada, ápice arredondado a obtuso ou levemente curtoacuminado, base cordada a truncada, raramente obtusa, margem crenada a crenulada; face adaxial escabra a lisa, às vezes esparsamente hirtela a estrigosa; face abaxial pubescente a hirtela ou esparso-tomentosa sobre as nervuras; venação geralmente craspedódroma, impressa na face adaxial, proeminente na abaxial, nervuras laterais 5-12 pares; pecíolo (0,5-)1,3-6,5(-8,0) cm compr., hirsuto a pubescente; estípulas triangulares, 2-7 mm compr., coriáceas, esparsamente hispidulosa. Inflorescência ereta ou pêndula, 4,5-17,3 cm compr.; pedúnculo (0,7-)1,5-9,3(-12,5) cm compr., hirsuto a hirteloso; cenanto $0,8-2,5 \mathrm{~cm}$ diâm., discóide a orbicular, margem inteira, às vezes crenada; $1-3$ verticilos bracteais na margem; flores estaminadas: tépalas 2, 0,3-0,6 mm compr., 0,2-0,5 mm larg., livres ou conatas na base, cuculadas; estames 2, curvos no botão, filetes curtos, anteras basifixas; flores pistiladas: tépala 1, 1,5-2,3 mm compr., 0,4-0,8 mm larg., tubular; estilete filiforme, glabro. Drupa, 1,5-2,5 mm compr., 1,7-2,7 mm larg., endocarpo levemente tuberculado.

Material examinado: Minas Gerais, Serra do Cipó, Heringer \& Castellanos s.n., 3.III.1958, fl. (HERB 5964, SP); km 138, alt. 1800 m., A.P. Duarte 2274, 9.XII.1949 (RB).

Material adicional: Minas Gerais, Buenópolis, Curimataí, Simão, $1,8 \mathrm{~km}$ ao sul da Praça do Jatobá, em Curimataí, margens do Rio Simão, próximo a cachoeira em córrego que deságua no Rio Simão, 1753’44”S 
43057’25”W, $562 \mathrm{~m}$ alt., $R$. Mello-Silva et al. 2528, 27.I.2004, fl., fr. (MBM, NY, R, SPF); Datas, Rodovia Datas-Serro, Morro do Coco, $18^{\circ} 26^{\prime} \mathrm{S} 43^{\circ} 41^{\prime} \mathrm{W}, 1300-1330 \mathrm{~m}$ alt., R. Mello-Silva et al. CFCR 11731, 8.I.1988, fl., fr. (SPF); Diamantina, próximo ao antigo leito da estrada de ferro de Guinda, R. Simão et al. CFCR 11774, 9.I.1988, fl., fr. (GUA, SPF); Lagoa Santa, fazenda Olhos D’Água, Luiz Roth 14632, 20.XI.1962, fl., fr. (BHCB, CESJ). São Paulo, São Paulo, Cidade Universitária, J.R. Pirani et al. s.n, 27.X.1987, fl. (SPF 49021).

Dorstenia brasiliensis ocorre do norte da Argentina e Uruguai até a Venezuela e Guiana Francesa (Berg \& Simonis 2000, Castro 2006). No Brasil, é encontrada nas áreas úmidas de cerrados, caatingas e restingas abertas, assim como nas florestas amazônica e atlântica. Na Serra do Cipó, foi encontrada com flores em maio e setembro.

Indivíduos de $D$. brasiliensis apresentam ampla variação morfológica em suas estruturas vegetativas e reprodutivas, o que tem dificultado sua identificação e a delimitação específica. Essa grande plasticidade associada a inúmeros táxons com diagnoses imprecisas levou Berg (2001) a sinonimizar vários deles em $D$. brasiliensis. Na Serra do Cipó, são registradas apenas duas coletas de Dorstenia: uma delas poderia ser identificada como D. tubicina Ruiz \& Pavon (Duarte 2274) e a outra como D. heringeri Carauta \& C.Valente (Heringer \& Castellanos s.n., HERB 5964), porém aqui se adota a circunscrição mais ampla de $D$. brasiliensis (sensu Berg 2001), segundo a qual essas duas espécies são sinônimos dela.

\section{Ficus L.}

Árvores a arbustos, terrestres ou hemiepífitas, até $20 \mathrm{~m}$ alt.; raízes aéreas frequentemente presentes, anastomosadas; látex presente em toda planta, escasso ou abundante. Folhas espiraladas, raramente dísticas, subopostas ou subverticiladas; lâmina inteira, 1 ou 2 glândulas acropeciolares ou baselaminares geralmente presentes; margem inteira, raramente denteada; pecíolos planos ou canaliculados; estípulas geralmente terminais, totalmente amplexicaules, decíduas ou persistentes, deixando cicatriz horizontais. Inflorescência unissexuada (funcionalmente) ou raramente bissexuada (plantas monóicas ou ginodióicas - funcionalmente estaminadas ou pistiladas), receptáculo urceolado (sicônio), axilar, solitário ou aos pares, séssil ou pedunculado; ostíolo proeminente, plano, crateriforme ou anel circular a triangular; orobrácteas externas 2-6, geralmente imbricadas, glabras ou pubescentes; epibrácteas 2 ou 3, triangulares ou arredondadas; bractéolas interflorais presentes. Flores estaminadas numerosas, sésseis ou pediceladas; tépalas 2-6, livres ou conatas na base; estames 1 ou 2(3), 2-tecas, dorsifixas; pistilódio presente ou ausente. Flores pistiladas várias, sésseis ou pediceladas; tépalas 2-4, livres ou conatas na base; ovário súpero, livre, 1-ovulado; estilete 1, inteiro, lateral, diferentes comprimentos na mesma inflorescência; estigmas 1 ou 2, levemente filiforme. Drupa globosa a oval, exocarpo levemente membranáceo; endosperma presente.

Ficus compreende aproximadamente 750 espécies distribuídas principalmente nas regiões tropicais e subtropicais do mundo, com cerca de 120 espécies na região Neotropical, 64 delas referidas para o Brasil (Berg 2001, Berg \& Villavicencio 2004). É caracterizado, principalmente, pelo hábito arbóreo ou hemiepifítico; presença de látex leitoso e viscoso em todas as partes da planta; folhas com glândulas na base da lâmina (baselaminar) ou no pecíolo (acropeciolar); estípulas terminais bem desenvolvidas e geralmente amplexicaules e, sobretudo, pela inflorescência do tipo sicônio, isto é, uma inflorescência bissexuada, cimosa, com um receptáculo urceolado (sicônio), envolvendo as numerosas e diminutas flores estaminadas e pistiladas na antese. Os sicônios são popularmente denominados de figos, e as plantas que os produzem conhecidas como figueiras ou gameleiras.

No presente trabalho adota-se o estudo de Mello-Filho et al. (2001) para descrever a morfologia do sicônio e de algumas das suas estruturas, a saber: tegilo - bráctea solitária, decídua, semelhante a uma caliptra ou capuz que protege os sicônios quando jovens; epibrácteas - brácteas que estão posicionadas na base do sicônio, na porção distal do pedúnculo; orobrácteas - brácteas inseridas e arranjadas ao redor da abertura do sicônio, o ostíolo; e bractéolas - brácteas dispostas entre as flores no interior do sicônio.

\section{Chaves para as espécies}

1. Árvores, raramente hemiepífitas; raízes aéreas ausentes; 2 glândulas baselaminares na face abaxial da folha; 3 estames

3.4. F. obtusiuscula

1'. Árvores, geralmente hemiepífitas; raízes aéreas presentes; 1 glândula acropeciolar na face abaxial; 1 ou 2 estames.

2. Epibrácteas glabras internamente; estípulas glabras internamente.

3. Ramos 3-7 mm larg.; lâmina foliar 3,0-9,5 x 1,3-4,5 cm, face abaxial glabra, às vezes esparsamente pubescente sobre a nervura principal; pecíolo geralmente glabro; ostíolo crateriforme

3'. Ramos 4-17 mm larg.; lâmina foliar 7,5-29,7 x 4,5-19,5 cm, face abaxial densamente pubescente a hispidulosa, indumento mais concentrado sobre as nervuras; pecíolo densamente pubescente; ostíolo proeminente em anel circular 3.2. F. gomelleira

2'. Epibrácteas seríceas, tomentosas a vilosas internamente; estípulas seríceas internamente.

4. Lâmina foliar ovada a elíptica, base subcordada a cordada; face abaxial densamente pubescente a tomentosa

4'. Lâmina foliar obovada a oblonga, base cuneada a obtusa; face abaxial glabra 3.3. F. obtusifolia 
3.1. Ficus calyptroceras (Miq.) Miq., Ann. Mus. Bot. Lugd.-Bat. 3: 297. 1867.

Nomes vulgares: gameleira, gameleira-branca, figueira, figueira-branca (Lorenzi 2002, Carauta \& Diaz 2002a, Ragusa Neto 2002, Martins et al. 2007).

Fig. 2 B-I

Árvores, hemiepífitas, 3,5 a 18,0 m alt.; raízes aéreas presentes; ramos 6-15 mm larg., angulares a levemente eretos, rugosos a canaliculados, glabros a levemente pubescentes ou tomentosos, periderme às vezes desprendendo-se. Lâmina foliar coriácea, (4,2-)9,3-13,8(-15,5) cm compr., (4,3-)6,5$10,2(-12,3) \mathrm{cm}$ larg., cordiforme ou ovada a elíptica, ápice arredondado a obtuso ou subagudo, base cordada a subcordada, margem inteira, geralmente revoluta; face adaxial glabra a esparso-hirsuta, levemente pubescente ao longo das nervuras e densamente na base da nervura primária, lisa a rugosa ao toque; face abaxial densamente pubescente a tomentosa sobre as nervuras, macia ao toque, glândula acropeciolar presente; nervura principal geralmente não atingindo o ápice, nervuras laterais 6-10 pares, pares basais distintos, ramificados, demais nervuras laterais geralmente furcadas distalmente, venação terciária reticulada a escalariforme; pecíolo (1,4-)2,5-4,3($5,8) \mathrm{cm}$ compr., (1,2-)2,0-3,5(-5,2) cm larg., levemente pubescente, raramente glabro, levemente canaliculado, periderme persistente ou desprendendo-se distalmente; estípulas $0,4-1,3 \mathrm{~cm}$ compr., densamente tomentosas a vilosas, seríceas internamente, às vezes decíduas, macias ao toque. Sicônios subglobosos a globosos, 6-15 mm compr., 5-13 $\mathrm{mm}$ larg., axilares, sésseis, aos pares, inicialmente envoltos por caliptra, leve a densamente pubescente, raramente glabros, máculas esverdeadas a marrom-enegrecidas ou avermelhadas; epibrácteas 1,0-4,2 mm compr., 3,5-6,3 mm larg., densamente seríceas a vilosas interna e externamente, fusionadas, às vezes separadas, triangulares a arredondadas, ápice levemente agudo, margem serícea; ostíolo 1,5-2,7 mm diâm., proeminente, raramente plano; orobrácteas geralmente 3 , caliptriformes, pubescentes a levemente seríceas, glabras internamente; bractéolas 0,5-1,2 mm compr., 0,3-0,7 mm larg., triangulares a lanceoladas. Flores estaminadas: pediceladas, $(0,7-) 1,2-1,5(-1,8) \mathrm{mm}$ compr., 0,4-0,8 mm larg.; tépalas 3, glabras; estame 1 . Flores pistiladas: sésseis ou pediceladas, (1,2-)2,3-3,0(-4,5) mm compr., 0,5-1,2 mm larg., tépalas (2)3(4), fusionadas ou não na base; estigma penicelado. Drupa subglobosa a ovóide, 0,8-1,7 mm compr., 0,5-1,5 mm larg.; semente 1, ovóide.

Material examinado: Minas Gerais, Cardeal Mota, Morro da Pedreira ( $2^{\circ} \mathrm{Grupo}$ ), afloramentos de calcários na base da Serra do Cipó, fazenda Canto da Serra, J.R. Pirani et al. CFSC 13274, 22.VII.1993, fl., fr. (SPF); afloramentos de calcários, D.C. Zappi et al. CFSC 10452, 7.IX.1987, fl., fr. (GUA, SPF); APA Morro da Pedreira, alto dos afloramentos de metacalcário (blocos do Grupo I), 19¹8'23.3"'S 43036'54.9”W, 959 m alt., E.G.A. Martins et al. 108, 23.V.2007, fl., fr. (SPF); 19¹8'29.6”S 43036'52.5”W, 924 m alt., E.G.A. Martins et al. 42, 24. IX.2006, fl., fr. (SPF); 19018'19.3"S 43036'50"W, 920 m alt., E.G.A. Martins et al. 51, 17.I.2007, fl., fr. (SPF); Santana do Riacho, Serra do Cipó, ao longo da rodovia Belo Horizonte - Conceição do Mato Dentro, estrada de acesso ao Morro do Calcário, M.L. Kawasaki et al. CFSC 7605, 7.X.1981, fl., fr. (SP, SPF). Serra do Cipó (Serra da Lapa), distrito São José da Cachoeira, afloramentos de calcários na estrada Santana do Riacho - Santana do Pirapama, V.C. Souza et al. 32887, 20.II.2007, fl. (ESA, SPF).

Ficus calyptroceras possui ampla distribuição geográfica, estendendo-se principalmente do Brasil ao leste da Bolívia, Paraguai e norte da Argentina, em matas mesófilas semidecidual e decidual, em campo-cerrado ou cerrado (Berg 2001, Berg \& Villavicencio 2004). No Brasil, ocorre no Sudeste, Centro-Oeste e no Nordeste, frequentemente associada a rochas calcárias e basálticas acima de $800 \mathrm{~m}$. No Nordeste, é muito comum na caatinga arbórea do vale do Rio São Francisco. Na Serra do Cipó, ocorre na orla ou no interior de matas deciduais associadas a afloramentos de calcários, sendo comum na Área de Proteção Ambiental Morro da Pedreira, um complexo orográfico constituído por afloramentos de calcário com 880-940 m altitude que antigamente sediava uma mineradora. Sua preferência por substratos rochosos carbonáticos já foi constatada por outros autores (Carauta et al. 1996, Berg \& Villavicencio 2004) e a espécie já foi registrada em afloramentos calcários de florestas estacionais deciduais a oeste da Cadeia do Espinhaço, geralmente árvores grandes, com suas sementes germinando em fendas de rocha, muitas vezes no topo dos afloramentos, à plena insolação, logo instalando longas raízes diretamente sobre a rocha, formando tronco robusto e copa ampla (Meguro et al. 2007).

3.2. Ficus gomelleira Kunth \& C.D. Bouché, Ind. Sem. Hort. Berol. (1846): 18. 1847; Albertoa 10, série Urticineae (Urticales): 67-68. 2002.

Nomes vulgares: figueira, gameleira, gameleira-vermelha, gomeleira (Romaniuc-Neto 1996; Carauta 1989, 1996; Carauta \& Diaz 2002a).

Fig. $3 \mathrm{~A}-\mathrm{H}$

Árvores, às vezes hemiepífitas, 8 a $15 \mathrm{~m}$ alt.; raízes adventícias presentes; ramos 4-17 mm larg., angulares, lisos, levemente canaliculados, pubescentes a glabros em direção a base dos ramos, periderme persistente, às vezes desprendendose na base. Lâmina foliar subcoriácea a coriácea, (7,5-)13,318,5(-29,7) cm compr., (4,5-)7,2-12,7(-19,5) cm larg., elíptica a oblonga, às vezes obovada, ápice arredondado a agudo ou acuminado, base arredondada a subcordada, margem inteira, levemente revoluta; face adaxial glabra a esparsohispidulosa, minutamente hispidulosa sobre as nervuras, lisa ao toque; face abaxial densamente pubescente a hispidulosa, indumento mais concentrado sobre as nervuras, amarelo a ferrugíneo, macio ao toque, glândula acropeciolar geralmente presente; nervuras laterais 7-10(-13) pares, ângulos iguais, proeminentes na face abaxial, venação terciária reticulada; pecíolo (1,3-)2,0-3,2(-5,3) cm compr., 0,2-0,7 mm larg., densamente pubescente, periderme desprendendo-se na base, às vezes persistente, canaliculado ou não; estípula $(0,5-) 0,8$ $1,5(-2,3) \mathrm{cm}$ compr., densamente tomentosa, ferrugínea a 


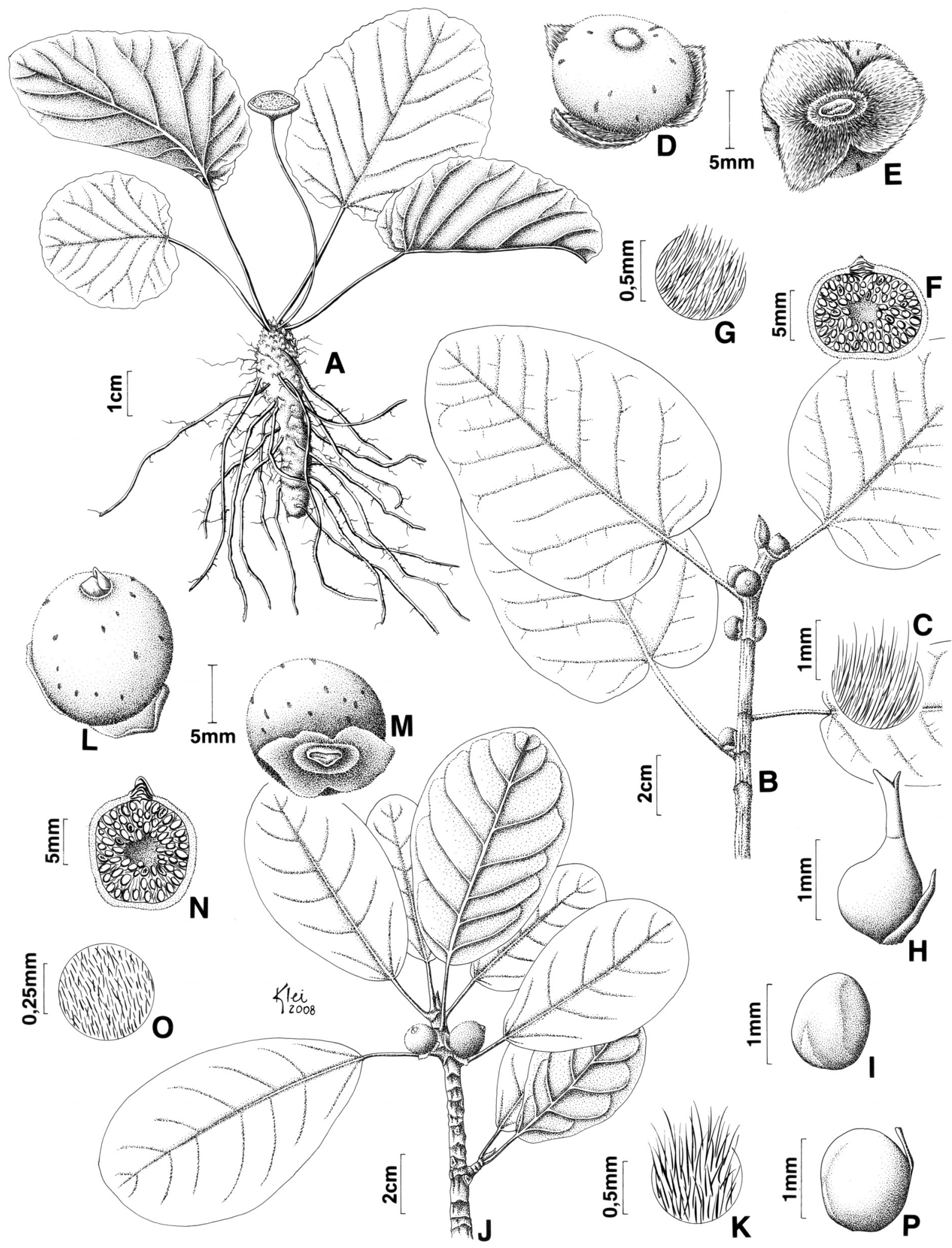

Fig. 2. A. Dorstenia brasiliensis. A. Hábito. B-I. Ficus calyptroceras. B. Ramo com folhas e sicônios. C. Detalhe do indumento de tricomas na face abaxial da lâmina. D. Vista apical do sicônio. E. Vista basal do sicônio. F. Corte longitudinal do sicônio. G. Indumento de tricomas do sicônio. H. Flor pistilada de estilete longo. H. Flor pistilada de estilete curto. I. Semente. J-P. F. obtusifolia. J. Ramo com folhas e sicônios. K. Indumento da base do sicônio. L. Vista apical do sicônio. M. Vista basal do sicônio. N. Corte longitudinal do sicônio. O. Indumento do sicônio. P. Fruto. A: Simão et. al. CFCR 11774. B-E: Martins et al. 51. F-I: Martins et al. 108. K-P: Martins et al. 46. 
castanho-avermelhada, glabra internamente, às vezes decídua, macia ao toque. Sicônios globosos a subglobosos, 5-13(-20) $\mathrm{mm}$ compr., 6-10(-18) mm larg., axilares, geralmente aos pares; caliptra geralmente presente, densamente pubescente a tomentosa, ferrugínea a castanho-avermelhada, máculas enegrecidas; pedúnculos 3-10(-15) mm compr.; epibrácteas 2, 3,3-6,0 mm compr., 3,0-5,2 $\mathrm{mm}$ larg., densamente tomentosas a pubescentes, glabras internamente levemente lobadas, separadas, raro fusionadas na base, arredondadas, ápice levemente agudo, margem glabra; ostíolo 1,7-2,5 mm diâm., anel circular proeminente; orobrácteas 2 , às vezes ausentes, glabras; bractéolas $0,5-1,0(-1,7) \mathrm{mm}$ compr., 0,2$0,5 \mathrm{~mm}$ larg., oblongas. Flores estaminadas: $0,7-1,5 \mathrm{~mm}$ compr., 0,4-1,0 mm larg.; tépalas 4, 2 em forma de caliptra, raramente fusionadas na base, glabras, pediceladas; estame 1, antera rimosa. Flores pistiladas: tépalas 3, $1 \mathrm{em}$ forma de caliptra, raramente fusionadas na base; estigma 1 , plumoso, bifurcado; flores pediceladas: pedicelo curto e espesso; $(0,3-$ ) 0,7-1,3 (-1,7) mm compr., 0,3-0,8 mm diâm., estilete curto; flores sésseis: 0,7-1,8 mm compr., 0,3-1,0 mm larg., estilete longo. Drupa globosa, 0,6-1,0 mm compr., 0,3-0,8 mm larg.; semente 1, ovóide.

Material examinado: Minas Gerais, Itambé do Mato Dentro, distrito de Santana do Rio Preto (Cabeça de Boi), 19²4'40.4"'S 43025'20.9'W, M.F. Santos \& E.G.A. Martins 162, 25.VIII.2007, fl., fr. (SPF).

Material adicional: Bahia, Itanhém, Corró, na base de afloramentos rochosos, 1707'15"S 4012'37.1'W, $300 \mathrm{~m}$ alt., J.R. Stehmann et al. 3785 , 17.VIII.2004, fl., fr. (BHCB, SPF). Minas Gerais, Gurinhatã, BR364, área de transição entre Cerradão e Floresta Estacional Semidecidual, 19¹3'37'S 5001'08'W, 522 m alt., L.F.M. Coelho et al. 7, 24.V.2007, fl. (SPF, SPFR); São Roque de Minas, arredores do Parque Nacional da Serra da Canastra, 20¹5'62"S 46024'58”W, 1095 m alt., A.M. Giulietti et al. CFCR 13595, 12.I.1994, fl., fr. (K, MBM, NY, SPF). São Paulo, Juquiá, fazenda Poço Grande, M. Kuhlmann 3114, 26.XI.1954, fr. (SPF).

Espécie que ocorre em praticamente toda a América do Sul, habitando florestas úmidas de baixas altitudes. No Brasil, ocorre desde os estados da Amazônia, passando pelo Nordeste e Sudeste até o Rio Grande do Sul (Carauta 1989, Carauta \& Diaz 2002a, Berg \& Villavicencio 2004, Martins et al. 2007). $\mathrm{Na}$ Serra do Cipó, ocorre apenas na face leste dos altiplanos, em floresta estacional semidecidual de baixa altitude.

Ficus gomelleira é facilmente identificada pela copa ampla, folhas com venação proeminente na face abaxial e pilosidade marrom a ferrugínea na estípula, no sicônio, no pecíolo, na lâmina foliar coriácea e, às vezes, também nos ramos. Berg \& Villavicencio (2004) comentam que a espécie é constantemente confundida com $F$. crocata (Miq.) Miq., principalmente pela morfologia do sicônio, mas da qual, segundo eles, pode ser diferenciada pelo indumento da estípula e pelos formato e venação foliares.

3.3. Ficus obtusifolia Kunth in Humb. \& Bonpl., Nov. Gen. Sp. 2: 49. 1817.

Nomes vulgares: figueira, pau-de-gamela (MendonçaSouza 2006, Carauta 1989).

\section{Fig. 2 J-P}

Árvores, hemiepífitas, 4 a $15 \mathrm{~m}$ alt.; raízes adventícias às vezes presentes; ramos 7-13 mm larg., angulares a levemente eretos, rugosos a canaliculados, glabros a pubescentes, periderme geralmente persistentes. Lâmina foliar coriácea a cartácea, (6,5-)10,3-20,5(-32,3) cm compr., (4,0-)7,5$11,3(-17,3) \mathrm{cm}$ larg., obovada a oblonga, raro oblanceolada a elíptica, ápice arredondado a obtuso, às vezes levemente curto-acuminado, base cuneada a obtusa, margem inteira, levemente revoluta; face adaxial glabra, às vezes esparsamente pubescente sobre a nervura principal, lisa a rugosa ao toque; face abaxial glabra, às vezes diminutamente pubescente sobre a nervura principal, lisa a rugosa ao toque, glândula acropeciolar presente; venação broquidódroma, nervuras laterais 5-8(9) pares, venação terciária reticulada; pecíolo (1,8-)2,5-5,3(-9,0) cm compr., (0,8-)1,5-3,2(-5,0) mm larg., diminutamente pubescente, raramente glabro, levemente canaliculado, periderme persistente; estípulas $(0,8-) 1,2-2,3$ $\mathrm{cm}$ compr., tomentosas a vilosas externamente, glabras a seríceas internamente, às vezes decíduas, macias ao toque. Sicônio subgloboso a globoso ou elipsóide, $12-23 \mathrm{~mm}$ compr., 10-17 mm larg., axilar, séssil ou pedúnculo até $6 \mathrm{~mm}$ compr., aos pares, inicialmente envolto por caliptra, densamente pubescente, alvo a acinzentado com máculas alaranjadas a marrom-avermelhadas; epibrácteas 2, 4,3-6,0 mm compr., 4,5-8,3 mm larg., tomentosas externamente, seríceas a vilosas internamente, separadas, às vezes fusionadas na base, triangulares a arredondadas, ápice levemente agudo, margem hirsuta; ostíolo 2,8-5,7 mm diâm., proeminente, raramente plano; orobrácteas 2(3), diminutamente pubescentes a glabras internamente, lineares; bractéolas 0,5-1,2 mm compr., 0,3$0,7 \mathrm{~mm}$ larg., triangulares a lanceoladas. Flores estaminadas: pediceladas, (0,8-)1,5-1,8(-2,2) $\mathrm{mm}$ compr., 0,6-1,0 $\mathrm{mm}$ larg.; tépalas 3, glabras; estame 1. Flores pistiladas: pedicelos maiores (1,7-)2,8-4,0(-5,5) mm compr., pedicelos menores 0,5-2,3 mm compr., 0,8-1,7 mm larg.; tépalas 3, fusionadas na base, levemente lobadas; estigma 1 , penicelado, às vezes bifurcado. Drupa subglobosa a oval, 1,2-2,3 mm compr., 0,81,8 mm larg.; semente 1, ovóide.

Material examinado: Minas Gerais, Itambé do Mato Dentro, Distrito de Santana do Rio Preto (Cabeça de Boi), margem do córrego, próximo da Trilha da Peroba, $19^{0} 24$ '59.2”S 43025'46.5”W, M.F. Santos \& E.G.A. Martins 163, 25.VIII.2007, fl. (SPF); imediações do Córrego Cipó, à meia altura da serra, $19^{\circ} 24^{\prime} 52.0^{\prime \prime}$ S $43^{\circ} 25^{\prime} 52.8^{\prime \prime W}$, M.F. Santos \& H. Serafim 283, 14.III.2008, fl. (SPF). Jaboticatubas, Serra do Cipó, estrada de acesso à Usina Coronel Américo Teixeira - UCAT, J. Semir et al. 4439, 5.IX.1973, fl., fr. (SP, UEC). Santana do Riacho, Serra do Cipó, ao longo da rodovia Lagoa Santa-Conceição do Mato Dentro: km 106, margem direita da rodovia, mata de encosta, E.G.A. Martins et al. 67, 13.II.2007, fr., fl. (SPF); margem esquerda da rodovia, camping Véu-daNoiva, base da Serra do Cipó, E. G.A. Martins \& P.T. Sano 68, 13.II.2007, bt. (SPF); km 87,5, ao longo do Rio Cipó, A.M. Giulietti et al. CFSC 7373, 1.VII.1981, fl., fr. (SP, SPF); Parque Nacional da Serra do Cipó, trilha Cânion das Bandeirinhas, ribeirão Mascates, E.G.A. Martins et al. 80, 14.II.2007, bt. (SPF); Parque Nacional da Serra do Cipó, entre a base da Serra e o Rio Cipó, A.P. Duarte, 6408, 26.X.1961 (RB); Santana do 
Riacho, estrada de acesso ao Pico do Breu, 16 $6^{0} 34^{\prime} \mathrm{S} 42^{0} 54^{\prime}, 900 \mathrm{~m}$ alt., área de pastagem, beira da estrada, E.G.A. Martins et al. 46, 23.IX.2006, fl., fr. (SPF).

Ficus obtusifolia ocorre principalmente do sudeste brasileiro ao Brasil Central e Norte, estendendo-se até a Bolívia e o sul do México, habitando em matas ciliares e florestas semideciduais de baixa altitude, em florestas úmidas da Amazônia e mais raramente nos cerrados do Brasil Central (Little Jr et al. 1974, Carauta 1989, Berg \& Villavicencio 2004, Mendonça-Souza 2006).

$\mathrm{Na}$ Serra do Cipó, ocorre na orla e no interior de matas ciliares localizadas no Cânion das Bandeirinhas e do ribeirão Mascate, situados no Parque Nacional. Ocorrem também indivíduos isolados em matas de encosta próximas à Cachoeira Véu-da-Noiva e em áreas degradadas ocupadas por pastagens nas imediações do Pico do Breu, em Santana do Riacho. Embora F. obtusifolia não seja típica de substratos carbonáticos, foi coletada nas mediações da Usina Coronel Américo Teixeira - UCAT, em um ambiente caracterizado por solo calcário e areno-pedregoso.

Ficus obtusifolia apresenta lâmina obovada a levemente subobovada e base cuneada a obtusa. Essas características são semelhantes às de F. catappifolia Kunth \& C.D. Bouché, F. mattogrossensis Standl. e F. gardneriana (Miq.) Miq., o que leva geralmente a identificações inacuradas. No entanto, Berg \& Villavicencio (2004) distinguem $F$. catappifolia de F. obtusifolia por apresentar pecíolo menor, base da lâmina levemente cordada e apenas duas orobrácteas visíveis. Carauta (1989) sinonimizou as outras espécies em $F$. obtusifolia, mas destacou aspectos do indumento do sicônio e do formato da base laminar capazes de diferenciá-las, os quais foram utilizados por Carauta \& Diaz (2002a) para o restabelecimento das duas espécies. Berg \& Villavicencio (2004), no entanto, propuseram novamente a sinonimização das três espécies, considerando os espécimes brasileiros morfologicamente variáveis e cujas características incluíam as definidas para $F$. mattogrossensis e $F$. gardneriana. Como verificado em São Paulo (Mendonça-Souza 2006), os materiais da Serra do Cipó também apresentam a gradação morfológica referida por Carauta (1989), Carauta \& Diaz (2002a) e Berg \& Villavicencio (2004). Portanto, adotou-se aqui a circunscrição ampla proposta por Berg \& Villavicencio (2004), considerando apenas F. obtusifolia ocorrente na Serra do Cipó.

3.4. Ficus obtusiuscula (Miq.) Miq., Ann. Mus. Bot. Lugd-Bat. 3: 300. 1867.

Nomes vulgares: figueira, figueira-branca, lombrigueira (Carauta 1989, Carauta \& Diaz 2002a, Mendonça-Souza 2006).

Fig. $3 \mathrm{I}-\mathrm{Q}$

Árvores, raramente hemiepífitas, $12-20 \mathrm{~m}$ alt.; raízes adventícias ausentes; ramos 3,0-8,5 mm larg., angulares a eretos, lisos, raramente canaliculados, glabros, periderme desprendendo-se, às vezes persistente. Lâmina foliar subcoriácea a cartácea, (7,0-)9,3-12,5(-14,0) cm compr., $(3,5-) 5,0-6,7(-7,5) \mathrm{cm}$ larg., elíptica a oblonga, ápice agudo a curto-acuminado, base aguda a cuneada, margem inteira, diminutamente revoluta; face adaxial glabra; face abaxial glabra, raramente pubescente sobre a nervura principal, 2 glândulas baselaminares presentes; nervuras laterais 1017 pares, ângulo distinto no $1^{\circ}$ par basal, proeminentes na face abaxial, venação terciária reticulada; pecíolo $(2,0-) 2,5-$ $3,2(-4,5) \mathrm{cm}$ compr., 0,2-0,4 mm larg., glabro, levemente canaliculado, periderme persistente; estípulas (1,5-)2,0$2,7(-3,3) \mathrm{cm}$ compr., glabras a esparso-pubescentes, glabras internamente, às vezes decíduas, rugosas. Sicônio, globoso, 5-8(-12) mm compr., 6-10(-13) mm larg., axilar, solitário, às vezes aos pares, máculas esverdeadas a enegrecidas; caliptra raramente presente; pedúnculo 2,0-3,5 $\mathrm{mm}$ compr.; epibrácteas 3, 0,7-1,5 mm compr., 1,0-2,0 mm larg., diminutamente pubescentes, glabras internamente, triangulares, separadas, às vezes fusionadas na base, arredondadas, ápice levemente agudo, margem glabra; ostíolo 1,0-1,5 mm diâm., proeminente; orobrácteas externas 5, diminutamente pubescentes na base; bractéolas 1,3-2,0(-2,5) $\mathrm{mm}$ compr., 0,2-0,5 mm larg., oblongas. Flores estaminadas: 1,4-2,3 mm compr., 0,4-1,5 mm larg.; tépalas 6, $2 \mathrm{em}$ forma de caliptra, ápice lobado, raramente fusionadas na base, glabras a diminutamente hispidulosas, pedicelo curto; estames 3 . Flores pistiladas: tépalas 6 , triangulares ou lanceoladas, livres; estigma 1, simples, reto; flores pediceladas: pedicelo curto $\mathrm{e}$ espesso, 2,0-3,5(-4,5) mm compr., 1,0-2,0 mm larg., estilete curto; flores sésseis: 1,0-2,5 mm compr., 0,8-1,6 mm larg., estilete longo. Drupa globosa, (1,6-)2,5-3,8(-5,0) mm compr., 1,0-02,5 mm larg.; semente 1, plana a levemente ovóide.

Material examinado: Minas Gerais, Itambé do Mato Dentro, distrito de Santana do Rio Preto (Cabeça de Boi), Propriedade do Sr. José Fernandes, 19²4'40.4'S 4325'20.9'W, M.F. Santos \& H. Serafim 543, 16.V.2007, st. (SPF). Santana do Riacho, Serra do Cipó, arredores da Usina Coronel Américo Teixeira - UCAT, Riachinho, M.A. Lopes \& P.M. Andrade s.n., 24.II.1985, fl., fr. (BHCB 8907); mata ciliar, P.M. Andrade \& M.A. Lopes s.n., 14.IV.1985, fl. (BHCB 9126).

Material adicional: Rio de Janeiro, Rio de Janeiro, Silva Jardim, Reserva Biológica Poço das Antas, margens do Rio São João, entre a BR-101 e a linha férrea, $22^{0} 30^{\prime} 00^{\prime \prime S} 42^{\circ} 15^{\prime} 00^{\prime \prime} \mathrm{W}$, M. Peron et al. 968, 30.XI.1992, fl., fr. (RB, SPF). São Paulo, Jardinópolis, margem do Rio Pardo, rodovia Anhanguera (SP-330 - sentido Ribeirão Preto Jardinópolis) sobre o Rio Pardo: km 331, 2103'57.1”S 47048'52.2”W, $500 \mathrm{~m}$ alt., R.A.S. Pereira et al. 148, 18.VII.2007, fr. (SPF, SPFR).

Ficus obtusiuscula está distribuída da Amazônia central ao Paraguai e norte da Argentina, habitando principalmente ambientes úmidos. No Brasil ocorre desde a Região Norte, passando por alguns estados do Nordeste e Centro-Oeste, ao Sudeste, principalmente em floresta atlântica, em matas ciliares inclusas no domínio do cerrado, sempre em baixas altitudes. Na Serra do Cipó, ocorre unicamente nas matas ciliares dos córregos e riachos que abastecem o reservatório aquático da Usina Coronel Américo Teixeira - UCAT. 
Entre as demais espécies do gênero na Serra do Cipó, Ficus obtusiuscula pode ser facilmente identificada pela presença de nervuras secundárias paralelas, 2 glândulas baselaminares, sicônios geralmente solitários e flores com 3 estames. $\mathrm{Na}$ Serra do Cipó, é a única espécie do subgênero Pharmacosycea Miq., caracterizado, dentre outras coisas, pelas flores com 3 estames. Está provavelmente relacionada a $F$. insipida Willd., com a qual pode ser confundida. Entretanto, diferenciase daquela espécie por apresentar sicônios, estípulas e folhas menores e com formatos diferentes, além de habitar preferencialmente ambientes úmidos. Estudos sobre anatomia foliar (Melo-Filho 1963; Leitão 1984) também corroboram a distinção entre essas duas espécies.

\subsection{Ficus pertusa L.f., Suppl. Pl.: 442. 1782 (non Bory} ex Miq. 1847).

Nomes vulgares: figueira, figueira d'água, gameleira, gameleira-da-folha-miúda, mata-pau (Crestana et al. 2006, Mendonça-Souza 2006).

Fig. $3 \mathrm{R}-\mathrm{X}$

Árvores, às vezes hemiepífitas, 4 a $10 \mathrm{~m}$ alt.; raízes adventícias presentes; ramos 3-7 mm larg., tortuosos a levemente eretos, rugosos a canaliculados, glabros, raramente pubescentes, periderme persistente, às vezes desprendendo-se. Lâmina foliar coriácea a subcoriácea, (3,0-)5,3-7,5(-9,5) cm compr., $(1,3-) 2,2-3,5(-4,5) \mathrm{cm}$ larg., ovada a subobovada ou elíptica, ápice acuminado a agudo, às vezes levemente arredondado, base cuneada a atenuada ou levemente aguda, margem inteira, levemente revoluta; face adaxial geralmente glabra, lisa a áspera ao toque; face abaxial glabra, às vezes diminutamente esparso-pubescente sobre a nervura principal, lisa a áspera ao toque, glândula acropeciolar presente; nervuras laterais 6-10(-11) pares, ângulo do par basal distinto, venação terciária reticulada; pecíolo (0,8-)1,7-2,8(-4,0) cm compr., (0,5-)1,2$1,5(-2,0) \mathrm{mm}$ larg., glabro, raramente pubescente, levemente canaliculado, periderme persistente, às vezes desprendendose na base; estípulas $(0,3-) 0,8-1,2(-1,6) \mathrm{cm}$ compr., glabras, às vezes esparso-pubescentes, castanho-avermelhadas a vináceas, glabras internamente, às vezes decíduas, macia ao toque. Sicônio subgloboso a globoso ou elipsóide a obovóide, 12$23 \mathrm{~mm}$ compr., 4-8 mm larg., axilar, pedunculado (pedúnculo 3-8 mm compr.), geralmente aos pares, caliptra geralmente ausente, geralmente glabro, amarelo-esverdeado com máculas alaranjadas a marrom-avermelhadas; epibrácteas 2, 4,36,0 $\mathrm{mm}$ compr., 4,5-8,3 mm larg., densamente tomentosas externamente, glabras a seríceas internamente, separadas, às vezes fusionadas na base, triangulares a arredondadas, ápice levemente agudo, margem hirsuta; ostíolo 2,8-5,7 mm diâm., crateriforme, raramente plano; orobrácteas 2(3), diminutamente pubescentes a glabras internamente; bractéolas $0,3-1,0 \mathrm{~mm}$ compr., 0,2-0,7 mm larg., triangulares a lanceoladas. Flores estaminadas: pediceladas, $(0,8-) 1,5-1,8(-2,2) \mathrm{mm}$ compr., $0,6-$ $1,0 \mathrm{~mm}$ larg.; tépalas 3, glabras; estame 1. Flores pistiladas: tépalas 3, em forma de caliptra, raramente fusionadas na base; estigma 1, plumoso, retos ou decurrentes; flores pediceladas: pedicelo curto e espesso, (0,5-)0,8-1,5 (-2,1) mm compr., 0,4$1,5 \mathrm{~mm}$ larg., estilete curto; flores sésseis: $0,8-2,8 \mathrm{~mm}$ compr., 0,3-1,4 mm larg., estilete longo. Drupa globosa a oval, 0,4-1,0 mm compr., 0,3-0,8 mm larg.; semente 1, ovóide.

Material examinado: Minas Gerais, Conceição do Mato Dentro, Serra do Cipó, rodovia Belo Horizonte - Conceição do Mato Dentro, ponte sobre o Rio Santo Antônio, 1904'23.5"S 43²6'43.2”W, 606 m alt., E.G.A. Martins et al. 57, 19.I.2007, bt. (SPF). Santana do Riacho, Serra do Cipó, ao longo da rodovia Belo Horizonte - Conceição do Mato Dentro, córrego Mãe d'Água, J.R. Pirani et al. CFSC 7597, 8.X.1981, fl. fr. (SP, SPF).

Material adicional: Minas Gerais, Gurinhatã, BR-364, área de transição entre Cerradão e Floresta Estacional Semidecidual, $19^{0} 19^{\prime} 40.5$ "S 49049'35.5”W, $542 \mathrm{~m}$ alt., L.F.M. Coelho et al. 9, 24.V.2007, fl., fr. (SPF, SPFR).

Ficus pertusa ocorre do sul do México e América Central à América do Sul, habitando florestas úmidas, semideciduais a deciduais, em altitudes até $2000 \mathrm{~m}$. No Brasil, há registros para quase todos os estados, porém com maior expressão ao longo do eixo norte-sudeste (Berg \& Villavicencio 2004, Carauta 1989, Carauta e Diaz 2002a). Na Serra do Cipó, ocorre na margem do rio Santo Antônio e no vale do córrego Mãe d'Água.

Essa espécie é reconhecida pelas folhas pequenas, glabras, sicônios curtamente pedunculados com o ostíolo geralmente crateriforme rodeado por um anel circular bem visível. Carauta (1989) verificou que essa espécie é muito confundida com $F$. perforata L., a qual difere principalmente pelo ostíolo frequentemente plano. Sua distinção de $F$. arpazusa Casar., $F$. citrifolia Mill. e $F$. guaranitica Chodat também é problemática (Berg et al. 1984, Carauta 1989, Berg \& Villavicencio 2004, Mendonça-Souza 2006). Carauta (1989) incluiu F. arpazusa na sinonímia de $F$. Citrifolia, enquanto Berg \& Villavicencio (2004) trataram F. arpazusa como sinônimo de F. pertusa.

Ficus pertusa parece compor um complexo muito variável segundo vários autores (Berg \& Simonis 1981, Berg 1989, Carauta 1989, Berg \& Villavicencio 2004, Mendonça-Souza 2006). Berg \& Villavicencio (2004) reconheceram três formas para os materiais brasileiros: 'arpazusa-form' - leste brasileiro (Bahia, Espírito Santo, leste de Minas Gerais, Paraná, Rio de Janeiro, Rio Grande do Sul, São Paulo e Santa Catarina), apresentando sicônios médios a grandes (1-1,5 cm diâm.), com ostíolo geralmente crateriforme; 'padifoliaform' - Amazônia extra-brasileira e em toda a América do Sul e Central, apresentando sicônios amplos, com ostíolo não crateriforme; e 'subtriplinervia-form' - Goiás e oeste de Minas Gerais, apresentando sicônios pequenos (3-8 mm diâm.) e maculados, com pedúnculo curto. Mendonça-Souza (2006), no entanto, adotou o conceito de Carauta (1989) e manteve as três espécies distintas: $F$. pertusa, com folhas de base e ápice agudos; F. guaranitica, com folhas de base cordada e ápice acuminado e sicônios piriformes com ostíolo plano; e F. citrifolia, com folhas de base truncada e ápice longoacuminado e sicônios globosos com ostíolo crateriforme, maiores que os de $F$. pertusa. 


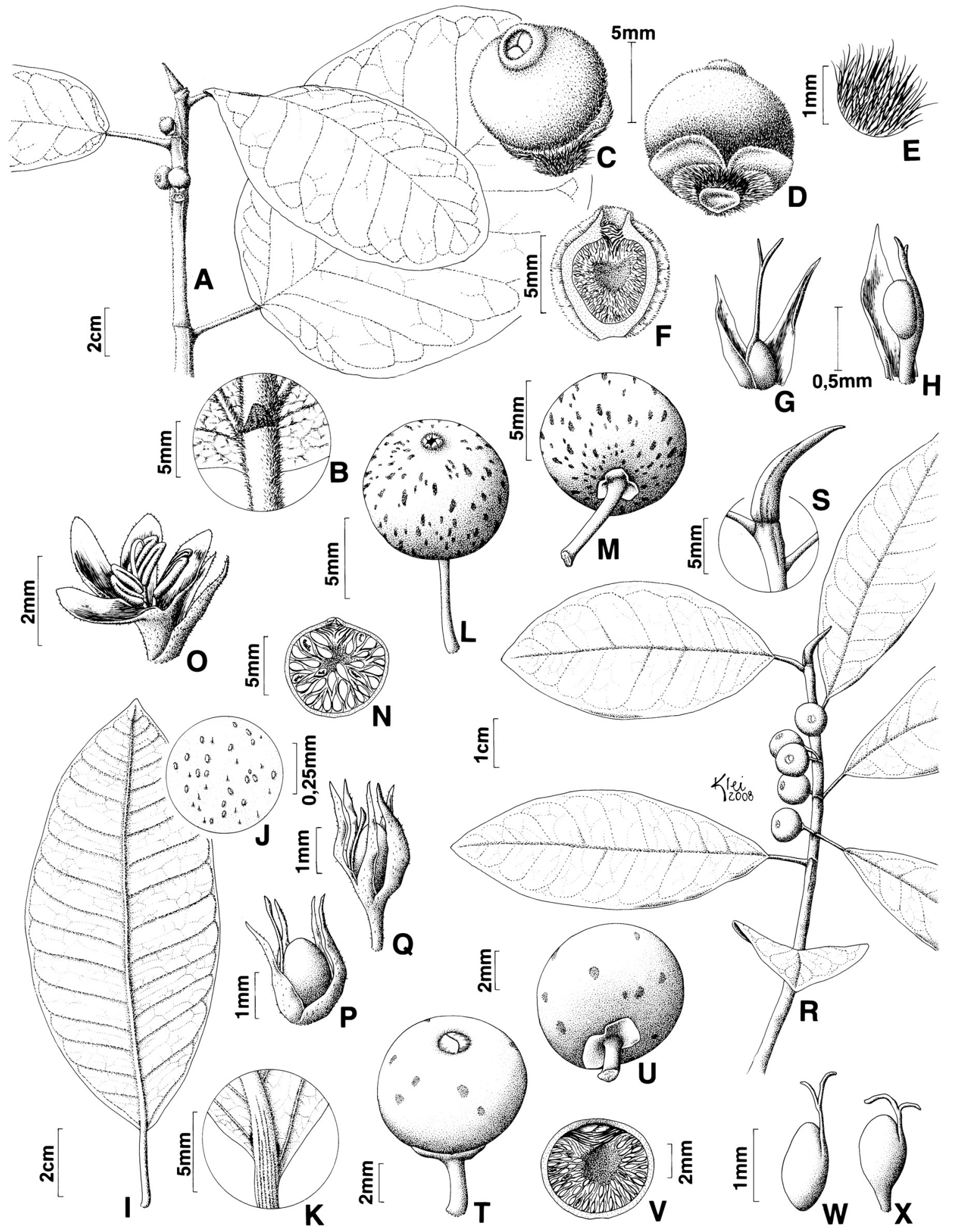

Fig. 3. A-H. Ficus gomelleira. A. Ramo com folhas e sicônios. B. Detalhe da face abaxial da lâmina, mostrando a glândula acropeciolar. C. Vista apical do sicônio. D. Vista basal do sicônio. F. Corte longitudinal do sicônio. G. Flor pistilada de estilete longo. H. Flor pistilada de estilete curto. I-Q. F. obtusiuscula. I. Folha. J. Detalhe do indumento de tricomas da face abaxial da lâmina. K. Detalhe da face abaxial da lâmina, mostrando as glândulas baselaminares. L. Vista apical do sicônio. M. Vista basal do sicônio. N. Corte longitudinal do sicônio. O. Flor estaminada. P. Flor pistilada de estilete curto. R-X. F. pertusa. R. Ramo com folhas e sicônios. S. Detalhe da estípula. T. Vista apical do sicônio. U. Vista basal do sicônio. V. Corte longitudinal do sicônio. W. Flor pistilada de estilete longo. X. Flor pistilada de estilete curto. A-H: Santos \& Martins 162. I-Q: Lopes \& Andrade BHCB 8907. R-X: Pirani et al. CFSC 7597. 


\section{Helicostylis Trécul}

Árvores até $12 \mathrm{~m}$ alt., ramos monopodiais. Folhas dísticas; lâmina inteira, margem inteira, frequentemente marromferrugínea quando seca, geralmente pubescente, tricomas globosos ou oblongo-capitados; venação broquidódroma; pecíolo levemente canaliculado, tomentoso a pubescente; estípulas pequenas, livres, semi-amplexicaules, decíduas. Inflorescências unissexuadas (plantas monóicas ou dióicas), unifloras, brácteas interflorais ausentes; inflorescências estaminadas geralmente axilares, discóides, pedunculadas, fasciculadas, às vezes aos pares, receptáculo revoluto quando jovem. Flor: tépalas (3-)4, lobadas ou partidas, geralmente livres, às vezes conatas na base; estames (2-)4, 2 verticilos frequentemente assimétricos, filetes retos no botão, alongados, conectivos estreitos ou amplos; pistilódio raramente presente; inflorescências pistiladas axilares, solitárias, às vezes aos pares, sésseis ou pedunculadas; flor: tépalas 4, lobadas a partidas, às vezes livres; ovário adnato lateralmente à base do perianto; estilete espiralado; estigmas 2, filiformes, retos ou curvos. Fruto adnato ao perianto expandido, endocarpo levemente crustáceo; sementes geralmente grandes.

O gênero compreende sete espécies distribuídas pela América Central e Sul (Berg 1972, 2001; Carauta 1996; Berg \& Simonis 2000), ocorrendo principalmente desde a Costa Rica e Panamá até a Bolívia e leste do Brasil.

4.1. Helicostylis tomentosa (Poepp. \& Endl.) Rusby, Mem. Torrey Bot. Club 6: 120. 1896.

Nomes vulgares: mão-de-gato, pau-de-letras (Carauta 1996).

\section{Fig. 4 A-E}

Árvores até $10 \mathrm{~m}$ alt.; ramos foliares, 3-8 mm larg., pubescentes a tomentosos, às vezes hirtelos; látex amarelado. Lâmina foliar cartácea a coriácea, $(3,0-) 7,5-15,0(-28,0) \mathrm{cm}$ compr., (2,0-)3,3-8,0(-10,3) cm larg., elíptica a oblonga ou lanceolada, mais ampla próxima ao ápice, assimétricas, ápice acuminado a mucronado, às vezes agudo, base aguda a obtusa, raramente truncada a emarginada, margem inteira, às vezes denticulada próximo ao ápice; face adaxial esparso-hirsuta a glabra, levemente pubescente sobre a nervura principal; face abaxial densamente tomentosa a pubescente, às vezes hirtela; venação impressa na face adaxial, proeminente na face abaxial, 8-16 pares nervuras laterais, nervuras terciárias reticuladas a escalariforme; pecíolo $0,4-1,2 \mathrm{~cm}$ compr., tomentoso; estípulas $0,3-1,0 \mathrm{~cm}$ compr., tomentosas a levemente seríceas. Inflorescências estaminadas várias, geralmente 12, 2,07,5 mm diâm.; pedúnculo 2-10 $\mathrm{mm}$ compr., pubescente a tomentoso; brácteas involucrais presentes, geralmente em 4 verticilos; flor: tépalas lobadas a partidas, $0,6-1,5 \mathrm{~mm}$ compr., densamente pubescentes próximo ao ápice; estames 4 , filetes 0,8-3,0 mm compr., externos mais curtos que os internos; anteras 0,2-0,7 $\mathrm{mm}$ compr., 0,2-0,4 $\mathrm{mm}$ larg., apiculadas ou não, conectivos estreitos ou amplos; estaminódios raramente presentes. Inflorescências pistiladas solitárias, às vezes envoltas por 1-2 inflorescências estaminadas, pedunculadas,
3,5-6,5 mm diâm., hemisféricas a subglobosas; pedúnculo 4,0$8,0 \mathrm{~mm}$ compr., pubescente a tomentoso; brácteas presentes, ovadas a agudas, levemente pubescentes; flor: tépalas partidas, 1,0-1,8 $\mathrm{mm}$ compr.; estilete $0,5-1,3 \mathrm{~mm}$ compr., lateral, levemente piloso próximo ao ápice; estigma filiforme, 1,5-3,8 mm compr., levemente curvo. Infrutescências 1,54,8 cm diâm., subglobosas a globosas; perianto expandido, levemente tomentoso; fruto 4-6 $\mathrm{mm}$ compr., $3 \mathrm{~mm}$ larg.

Material examinado: Minas Gerais, Itambé do Mato dentro, Distrito de Santana do Rio Preto (Cabeça de Boi), fazenda José Agostinho, 19²3'46.9'"S 4324'07.4'W, M.F. Santos \& H. Serafim 336, 16.III.2008, fl., fr. (SPF); M.F. Santos \& L.M. Borges 538, 15.XII.2007, fl., fr. (SPF); M.F. Santos \& L.M. Borges 620, 15.XII.2008, fl., fr. (SPF); M.F. Santos \& L.M. Borges 540, 15.XII.2007, fl., fr. (SPF).

Material adicional: Bahia, Ilhéus, Rodovia Ilhéus-Itacaré (BA 001), km 20, acesso ao Retiro e para a Lagoa Encantada, 14035'10"S 3907'2”W, $170 \mathrm{~m}$ alt., P. Fiaschi et al. 2676, 27.XI.2004, fl. (CEPEC, SPF); Uruçuca, estrada de Serra Grande para Uruçuca, Mata da Torre do Celular, 14029'59'S 3906'54'W, $380 \mathrm{~m}$ alt., P. Fiaschi et al. 2054, 18.III.2004, fl., fr. (CEPEC, SPF); Valença, estrada de Valença para Guaibim, RPPN Água Branca, 13019'44”S 39 5'25”W, $220 \mathrm{~m}$ alt., $P$. Fiaschi et al. 2142, 28.III.2004, fr. (CEPEC, SPF).

Helicostylis tomentosa está distribuída desde a Venezuela ao oeste andino e litoral sudeste brasileiro, habitando principalmente em florestas úmidas acima de $1600 \mathrm{~m}$ alt. (Berg 1972, Carauta 1996). No Brasil, ocorre na Amazônia e nos estados do Centro-Oeste e Sudeste; no Nordeste, há registros apenas para a Bahia. Em Minas Gerais, essa espécie é considerada rara, encontrada principalmente no domínio atlântico nos Vales do Rio Doce e do Paraíba do Sul, em florestas do tipo estacional semidecidual das terras baixas e montanas e baixo-montana (Stevens 2001; Oliveira Filho 2006). Na Serra do Cipó, ocorre na floresta estacional semidecidual da face leste, florescendo e frutificando em março, agosto, novembro e dezembro.

Helicostylis tomentosa é variável em relação ao indumento dos ramos e folhas, que podem ser pubérulos, hirsutos, tomentosos ou hirtelos, com a face abaxial das folhas esparsa a densamente indumentada. Assim como afirmara Berg (1972) são encontradas situações intermediárias entre todos esses tipos de indumento, e o mesmo se verifica nas várias formas de folhas observadas na espécie, havendo uma aparente relação dessas variações com a idade da planta. As inflorescências pistiladas são sésseis ou frequentemente pedunculadas, e a dimensão e forma dos estames são também muito diversas.

\section{Maclura Nutt.}

Árvores ou arbustos, até $10 \mathrm{~m}$ alt., às vezes escandentes, armados; látex levemente amarelado. Folhas dísticas ou espiraladas; lâmina inteira a levemente lobada, margem serreada a denteada; pecíolo plano, pubescente a glabro; estípulas livres ou conatas, laterais, semi-amplexicaules. 
Inflorescências unissexuadas (plantas dióicas), axilares, geralmente multifloras, bracteadas, glândulas amareladas a esverdeadas presentes, imersas nas brácteas e no perianto expandido; inflorescências estaminadas racemosas, globosocapitadas ou espiciformes; flores: sésseis ou pedunculadas; tépalas (3)4, livres ou conatas, decussadas ou imbricadas; estames 4, curvos no botão; pistilódio presente, oblongo, plano; inflorescências pistiladas globoso-capitadas; flores: tépalas 4 , lobadas ou partidas, tubulares, decussadas; ovário livre, estigmas (1)2, assimétricos, filiformes. Fruto composto e policárpico, drupáceo, perianto expandido, carnoso, endocarpo crustáceo; semente pequena, endosperma presente.

Maclura é composto por 11 espécies com distribuição exclusivamente tropical. Três espécies ocorrem nas Américas desde os Estados Unidos até a Argentina, duas destas com ampla distribuição: M. tinctoria (L.) D. Don ex Steud. e M. brasiliensis (Mart.) Endl., sendo que a primeira espécie apresenta aproximadamente 80 sinônimos (Berg \& Simonis 2000; Lachance et al. 2001).

No Brasil, essas duas espécies ocorrem desde a região amazônica até o sul do país habitando principalmente na orla de formações secundárias e matas abertas sobre solos úmidos de planícies aluviais (Durigan \& Nogueira 1990). De acordo com as características sucessionais, é classificada como pioneira ou clímax exigente de luz (Durigan \& Nogueira 1990).

\subsection{Maclura tinctoria (L.) D. Don ex Steud., Nomencl.} Bot. (ed. 2) 2: 87. 1841.

Nomes vulgares: amora-branca, amoreira-brava, amorado-mato, jataíba, taiúva, taiuveira, tajuba, tatá-iva, tatajuva, tatané, taúba (Carauta 1996, Lorenzi 2002, Battilani et al. 2006, Crestana et al. 2006, Martins et al. 2007)

Fig. 4 F-I

Árvores ou arbustos, até $6 \mathrm{~m}$ alt., eretas, ramos armados, em 'zig-zag', glabros a levemente pubescentes; espinhos axilares, solitários ou aos pares, eretos; pequenas estípulas geralmente presentes, triangulares. Lâmina foliar membranácea a cartácea, (2,0-)3,7-8,5(-13,0) cm compr., $(1,2-) 2,5-4,0(-5,5) \mathrm{cm}$ larg., elíptica a oblonga, raramente lanceolada a obovada, levemente assimétrica, ápice agudo a acuminado, às vezes caudado, base obtusa a arredondada ou cordada, margem lobada ou denteada a serreada; face adaxial esparsamente hirsuta; face abaxial glabra a esparsohirsuta, tomentosa a hirsuta sobre as nervuras; venação semicraspedódroma a broquidódroma, nervuras impressas na face adaxial, proeminentes a impressas na face abaxial, nervuras laterais 6-12 pares, nervuras terciárias geralmente ausentes; pecíolo $0,2-1,0(-1,8) \mathrm{cm}$ compr., levemente hirsuto a tomentoso; estípulas 2-7 mm compr., pubescentes, pontiagudas. Inflorescências estaminadas racemosas, 2,0-9,5 cm compr., axilares, espigadas ou espiciformes, geralmente solitárias, pedunculadas; pedúnculo 0,3-1,2 cm compr., densamente pubescente a tomentoso; flores: tépalas 3 ou 4, 0,4$1,2 \mathrm{~mm}$ compr., livres a conduplicadas, sésseis, entremeadas por brácteas glandulares, densamente pubescentes; estames curvos no botão, filete $1,5-2,3 \mathrm{~mm}$ compr., anteras $0,2-0,6$ $\mathrm{mm}$ compr., 0,3-0,7 mm larg.; pistilódio 0,2-0,7 mm compr., plano, membranoso, apiculado; inflorescências pistiladas subglobosas a capitadas, $2-5 \mathrm{~mm}$ diâm., axilares, geralmente solitárias, pedunculadas; pedúnculo $0,3-1,5 \mathrm{~cm}$ compr., pubescente a levemente tomentoso; flores: tépalas 4, 0,6-1,0 $\mathrm{mm}$ compr., livres a conatas, sésseis, decussadas, cuculadas, densamente pubescentes próximo ao ápice; ovário $0,3-0,8$ $\mathrm{mm}$ compr., estilete 2,5-5,0 mm compr., filiforme, persistente no fruto, estigma indiviso, pubescente; brácteas interflorais presentes, 0,6-1,0 mm compr., cuculadas, glândulas presentes próximo ao ápice. Fruto composto de várias núculas comprimidas, 0,7-1,5 cm compr., 0,5-1,3 cm larg., globoso a oblongo, carnoso, indeiscente, com aroma adocicado; semente achatada lateralmente, oval, lisa.

Material examinado: Minas Gerais, Itambé do Mato Dentro, distrito de Santana do Rio Preto (Cabeça de Boi), fazenda José Agostinho, 19²4'04.1"S 43024'02.37'W, M.F. Santos \& E.G.A. Martins 177, 26.VIII.2007, fl., fr. (SPF); propriedades do Nem, 19024'03.5”S 43024'08.5”W, M.F. Santos \& H. Serafim 114, 13.II.2007, fl. (SPF); Estrada das Posses, após a fazenda José Agostinho, em direção à Mata do Cachoeirão, 19²5'54.7'S 43025'58.3”W, M.F. Santos \& L.M. Borges 204, 18.VII.2007, fl., fr. (SPF).

Material adicional: Minas Gerais, Descoberto, Reserva Biológica da Represa do Grama, R.M. Castro et al. 875, 30.I.2004, fl., fr. (CESJ, SPF); Matozinhos, APA Carste de Lagoa Santa, fazenda Caucaia, A.E. Brina \& L.V. Costa s.n., 2.III.1996, fl., fr. (BHCB 36346).

Maclura tinctoria apresenta ampla distribuição neotropical, ocorrendo desde o sul do México à Argentina. No Brasil, é encontrada em quase todas as regiões, crescendo em formações secundárias, e matas abertas (Carauta 1996; Martins et al. 2007). Em Minas Gerais, M. tinctoria é comum, ocorrendo tanto em regiões de domínio de Mata Atlântica (Vale do Jequitinhonha, Vale do Mucuri-Itanhém, Vale do Rio Doce, Vale do Paraíba do Sul, Alto do Rio Grande, Mantiqueira Sul e Planalto de Poços de Caldas) quanto no Cerrado (Espinhaço Sul, Noroeste e Triângulo) e em matas secas (Oliveira Filho 2006). Na Serra do Cipó, essa espécie ocorre em mata estacional semidecidual e ao longo da mata ciliar do Rio Preto, nas imediações da face leste da serra.

Segundo Pott e Pott (1994), o epíteto de M. tinctoria faz alusão à tinta amarela exsudada do caule e ramos, os quais apresentam propriedades medicinais, sendo utilizados como cicatrizante e antiflamatório.

Maclura tinctoria apresenta período curto de frutificação, porém produz, anualmente, grande quantidade de frutos na estação chuvosa, contribuindo para a oferta de recursos alimentares e amplo forrageamento durante esse período. Em complemento, Battilani et al. (2006) observou que a presença de aves frugívoras/onívoras varia intensamente ao longo do ano, tendo maior abundância quando há oferta massiva de flores e dos frutos carnosos dessa espécie em áreas de mata ciliar do Mato Grosso do Sul. Na Serra do Cipó, a espécie floresce de agosto a setembro e frutifica de novembro a janeiro. 


\section{Pseudolmedia Trécul}

Árvores, até $13 \mathrm{~m}$ alt.; ramos lisos, monopodiais, cicatrizes horizontais; látex branco a amarelado, enegrecido quando exposto ao ar. Folhas dísticas; lâmina inteira, margem geralmente inteira, densos tricomas pluricelulares, globoso-capitados, glândulas ausentes; pecíolo plano, glabro a levemente pubérulo; venação broquidódroma; estípulas livres, amplexicaules, decíduas. Inflorescências unissexuadas (plantas dióicas ou monóicas), geralmente axilares, discóide-capitadas, sésseis, unifloras, várias brácteas imbricadas, basifixas, cobrindo a superfície do receptáculo; inflorescências estaminadas sésseis, unifloras, discóides, livres; flor: perianto geralmente ausente, invólucro cobrindo os estames na antese; estames livres entremeados por brácteas dispostas concentricamente, filetes retos, anteras frequentemente apiculadas, ciliadas; pistilódio geralmente ausente, às vezes reduzido; inflorescências pistiladas sésseis, unifloras; flor: tépalas 4 , tubulares, denteadas, conatas; ovário adnato ao perianto; estigma 2, filiforme. Fruto drupáceo, perianto expandido na frutificação, carnoso ou suculento, endocarpo crustáceo; semente grande, endosperma ausente.

$O$ gênero compreende nove espécies amplamente distribuídas pela América tropical, desde o sul do México ao norte da Argentina (Berg \& Simonis 2000, Castro 2006). No Brasil, ocorre desde a Amazônia até Santa Catarina, habitando principalmente áreas de cerrado e matas.

6.1. Pseudolmedia laevigata Trécul, Ann. Sci. Nat. Bot., Sér. 3, 8: 131. 1847.

Nome vulgar: marurê (Carauta et al. 1996).

Fig. 1 F-J

Árvores, até 4,0 m alt.; ramos folhosos 1,0-3,2 mm larg., glabros, às vezes levemente pubescentes; látex esbranquiçado, tornando-se enegrecido. Lâmina foliar cartácea a coriácea, $(2,5-) 4,0-11,3(-14,5) \mathrm{cm}$ compr., (1,5) 2,5-3,5(-5,0) cm larg., elíptica a oblonga ou lanceolada, levemente assimétrica, ápice acuminado a agudo, base aguda a obtusa, às vezes emarginada, margem inteira, às vezes subdentada; face adaxial geralmente glabra, ás vezes pubérula sobre a nervura principal; face abaxial glabra a esparsamente pubérula; nervuras impressas na face adaxial, proeminentes na abaxial, nervuras secundárias 9-20 pares, nervuras terciárias reduzidas ou reticuladas; pecíolo 0,2$1,0 \mathrm{~cm}$ compr., glabro a pubescente; estípulas $0,3-1,2 \mathrm{~cm}$ compr., esparsa a densamente pubescentes. Inflorescências estaminadas globosas a subglobosas, 2-7 mm diâm., 1225 brácteas involucrais, reniformes, ovada a lanceoladas, esparso-pubescentes, dispostas em 4-8 verticilos; flores: perianto geralmente ausente, muitas brácteas interestaminais, 1,0-3,2 $\mathrm{mm}$ compr., pubescentes a glabras externamente, dispostas concentricamente; estames 1-3, 0,3-1,0 mm compr., anteras $0,7-1,0 \mathrm{~mm}$ compr., 0,2-0,4 mm larg., conectivo amplo; pistilódio geralmente ausente, às vezes reduzido. Inflorescências pistiladas 1,5-2,0 mm compr., isoladas; $8-15$ brácteas involucrais, reniformes a ovadas, obtusas a agudas, esparso-pubescentes, dispostos em 3-6 verticilos; flores: tépalas tubulares, 1,0-2,0 $\mathrm{mm}$ compr., esparsa a densamente pubescentes; ovário pubescente, estilete 0,3-0,8 mm compr., estigmas 2, 2,0-5,7 $\mathrm{mm}$ compr. Fruto amplo, envolto por perianto expandido, elipsóide, 6,5-8,5 mm compr., 4,3-5,2 $\mathrm{mm}$ larg., esparsopubescente, às vezes concentrado no ápice, carnoso a suculento; sementes 3,0-4,5 mm compr., 2,4-3,5 mm larg.

Material examinado: Minas Gerais, Santana do Riacho, ao longo da rodovia Belo Horizonte - Conceição do Mato dentro, córrego Mãe D’Água, J.R. Pirani et al. CFSC 7598, 8.X.1981, fl., fr. (SPF); Serra do Cipó, rodovia Lagoa Santa - Conceição do Mato Dentro: km 106, margem direita da rodovia, próximo a Cachoeira da "Capelinha", E.G.A. Martins et al. 66, 13.II.2007, bt. (SPF); Serra do Cipó, Parque Nacional da Serra do Cipó, trilha do Cânion das Bandeirinhas, margem direita, próximo ao paredão do Cânion, E.G.A. Martins \& P.T. Sano 75, 14.II.2007, bt. (SPF); Serra do Cipó, estrada para a Usina Dr. Pacífico Mascarenhas (ramal da rodovia Lagoa Santa - Conceição do Mato Dentro - MG 010), sobre o Ribeirão Indequicé, E.G.A. Martins et al. 50, 17.I.2007, fr. (SPF).

Material adicional: Minas Gerais, São Gonçalo do Rio Preto, Parque Estadual do Rio Preto, margem esquerda do rio, próximo a casa dos vigilantes, $18^{\circ} 07^{\prime} 26^{\prime}$ 'S $43^{\circ} 20^{\prime} 48^{\prime \prime} \mathrm{W}$, alt. $714 \mathrm{~m}$, F.N. Costa \& L.G. Lessa 1038, 22.II.2006, fl., fr. (SPF).

Pseudolmedia laevigata está distribuída desde o Panamá e leste andino até o Brasil, onde ocorre em toda a Região Norte, Bahia, Mato Grosso, Minas Gerais e São Paulo, habitando principalmente em matas úmidas e cerradão acima de $1500 \mathrm{~m}$ alt. (Berg 1972, Berg \& Simonis 2000). Em Minas Gerais, há registros da espécie apenas para a parte sul da Cadeia do Espinhaço, noroeste do estado e no Triângulo Mineiro, na orla ou interior de Floresta Estacional Semidecidual Alto Montana e em matas ciliares (Oliveira Filho 2006).

Na Serra do Cipó, a espécie ocorre em matas de encosta e ciliares, nas proximidades do Cânion das Bandeirinhas, situado dentro do Parque Nacional da Serra do Cipó, e na orla e interior das matas ciliares ao longo do Ribeirão Indequicé (ou Andrequicé).

Berg (1972) registrou a possibilidade dessa espécie florescer o ano todo, principalmente a partir de setembro a novembro. Entretanto, na Serra do Cipó foi coletada apenas com botões nos meses de janeiro e fevereiro e florescendo em outubro; frutos foram encontrados em outubro e janeiro.

\section{Sorocea A.St.-Hil.}

Árvores ou arbustos; ramos inermes, glabros a levemente pubescentes, lenticelas conspícuas frequentes. 
Folhas simples, alternas, dísticas; lâmina inteira, margem denteada a crenulada ou espinulada, glândulas ausentes; venação craspedódroma ou semicraspedódroma; pecíolo plano, geralmente glabro; estípula livre, lateral. Inflorescências unissexuadas (plantas dióicas), solitárias ou aos pares, axilares ou subaxilares, multifloras; brácteas pequenas, basifixas ou peltadas, cordiformes, ovadas ou suborbiculares; inflorescências estaminadas racemos, espigas ou subcapitadas; flores: tépalas 4, decussadas, imbricadas, geralmente conatas; estames $2-4$, livres, retos no botão, anteras basifixas, às vezes dorsifixas, extrorsas, conectivo amplo, frequentemente apiculado; pistilódio geralmente ausente; inflorescências pistiladas racemosas, às vezes subespigadas a subcapitadas; flores: tépalas 4 , lobadas, às vezes inteiras, tubulares, parte apical e basal distintas, parte basal adnata ao ovário; perianto expandido, pedicelo e pedúnculo carnosos, avermelhados a alaranjados na frutificação; estigma 2, simétricos, curtos. Fruto amplo, globoso a elipsóide, adnato ao perianto expandido; endocarpo coriáceo a subcrustáceo; semente grande, endosperma ausente, testa fina; cotilédones assimétricos.

Sorocea distribui-se por toda a região tropical e subtropical, com maior diversidade na América do Sule Central (RomaniucNeto 1996), compreendendo 14 espécies neotropicais (Berg \& Simonis 2000). Berg \& Akkermans (1985) propuseram novos táxons e combinações em Sorocea, sendo 13 táxons reconhecidos no Brasil, 10 deles concentrados na Amazônia e apenas três ocorrentes no sul e sudeste brasileiros. Burger et al. (1962) registraram uma quarta espécie ocorrendo na Mata Atlântica do sudeste brasileiro. Entretanto, vários autores (Burger et al. 1962, Berg \& Akkermans 1985, RomaniucNeto 1996) têm sugerido a necessidade de uma revisão das espécies do gênero ocorrentes no Brasil, principalmente das espécies da região oeste.

7.1. Sorocea guilleminiana Gaudich., Voy. Bonite, Bot. Atlas: t. 74. 1844.

Nomes vulgares: bainha-de-espada (Carauta 1993); canela-dourada, folha-de-serra (MG, Tameirão Neto 2654 BHCB).

Fig. $4 \mathrm{~J}-\mathrm{K}$

Árvores ou arbustos, até 10,0 m alt.; ramos folhosos 1,0-3,0 mm larg., glabros a esparsamente pubescentes, cicatrizes horizontais presentes. Lâmina foliar subcoriácea a coriácea, (4,5-)10,5-17,3(-20,0) cm compr., (1,5-)4,3$6,8(-8,5) \mathrm{cm}$ larg., elíptica a oblonga ou lanceolada, ápice acuminado, base aguda a obtusa, às vezes subcordada, margem espinulosa, nunca inteira, revoluta; face adaxial glabra; face abaxial glabra a esparsamente pubescente, levemente hirtela sobre a nervura principal; venação semicraspedódroma, impressa na face adaxial, proeminente na abaxial, 9-15 pares nervuras laterais, nervuras terciárias escalariforme; pecíolo $(0,2-) 0,5-1,0(-1,5) \mathrm{cm}$ compr., pubescente a glabro; estípula membranácea, 0,3-1,0 $\mathrm{cm}$ compr., pubescentes, decíduas a subpersistentes. Inflorescências estaminadas pêndulas, 1,5-5,0 cm compr., pedúnculo de 0,3-1,0 cm compr.; flores: tépalas partidas ou lobadas, esparso-pubescentes, cilioladas, pediceladas; estames 2-4, livres, filetes $0,5-1,0 \mathrm{~mm}$ compr., anteras 0,2-0,8 mm compr., 0,2-0,5 mm larg., conectivo amplo. Inflorescências pistiladas patentes ou pêndulas, $1,7-5,5 \mathrm{~cm}$ compr., pedúnculo 0,3-1,5 cm compr., pubescente; flores: tépalas lobadas a inteiras, esparso-pubescentes a glabras externamente, face abaxial densamente pubescente a hispidulosa, às vezes glabras, pediceladas ou subsésseis; pedicelo 2-4 mm compr., $0,3-1,0 \mathrm{~cm}$ compr. na frutificação, estilete longo, estigma subulado, 0,2-0,5 mm compr., papilas presentes. Frutos 0,4-1,0 cm compr., 3-7 mm larg., perianto expandido, globoso a elipsóide ou ovóide, ápice arredondado, superfície lisa a verrucosa ou muricado.

Material examinado: Minas Gerais, Itambé do Mato Dentro, distrito de Santana do Rio Preto (Cabeça de Boi), propriedades do José Agostinho, 19023'46.9”'S 43024'07.4”W, M.F. Santos \& L.M. Borges 541, 15.II.2007, fr. (SPF); córrego Cipó, à meia altura da serra, 19²4'52.0"S 43025'52.8”W, M.F. Santos \& E.G.A. Martins 170, 25.VIII.2007, st. (SPF); M.F. Santos \& H. Serafim 281, 14.III.2008, fl., fr. (SPF); propriedades do Nem, 19²3'49.2”S 43024'05.8”W, M.F. Santos \& E.G.A. Martins 134, 23.VIII.2007, st. (SPF). Santana do Riacho, Serra do Cipó, APA Morro da Pedreira (afloramentos de calcários na base da Serra do Cipó), 19¹8'34.3"S 43036'52.9"W, alt. 821 m, E.G.A. Martins et al. 44, 24.IX.2006, bt. (SPF); ao longo da rodovia Belo Horizonte - Conceição do Mato Dentro: km 128, R. Mello-Silva et al. CFSC 9775, 3.V.1986, fl. (SPF)

Material adicional: Minas Gerais, Descoberto, Reserva Biológica da Represa do Grama, F.R.G. Salimena s.n., 30.X.2000, fr. (CESJ 31437, SPF).

Sorocea guilleminiana é encontrada principalmente na América tropical, em regiões úmidas da Venezuela, Peru, Bolívia, Equador e leste brasileiro. No Brasil, ocorre desde a Amazônia, passando pelo Brasil Central até o sudeste brasileiro, tido como área de maior concentração de suas populações (Carauta 1993, Berg \& Simonis 2000; RomaniucNeto 1996).

$\mathrm{Na}$ Serra do Cipó, ocorrem indivíduos isolados no interior de floresta decidual associada a solos carbonáticos e na orla e interior de floresta estacional semidecidual da face leste da serra, e também em capão de mata do alto da serra. Floresce de agosto a outubro, com frutificação indo até março. 


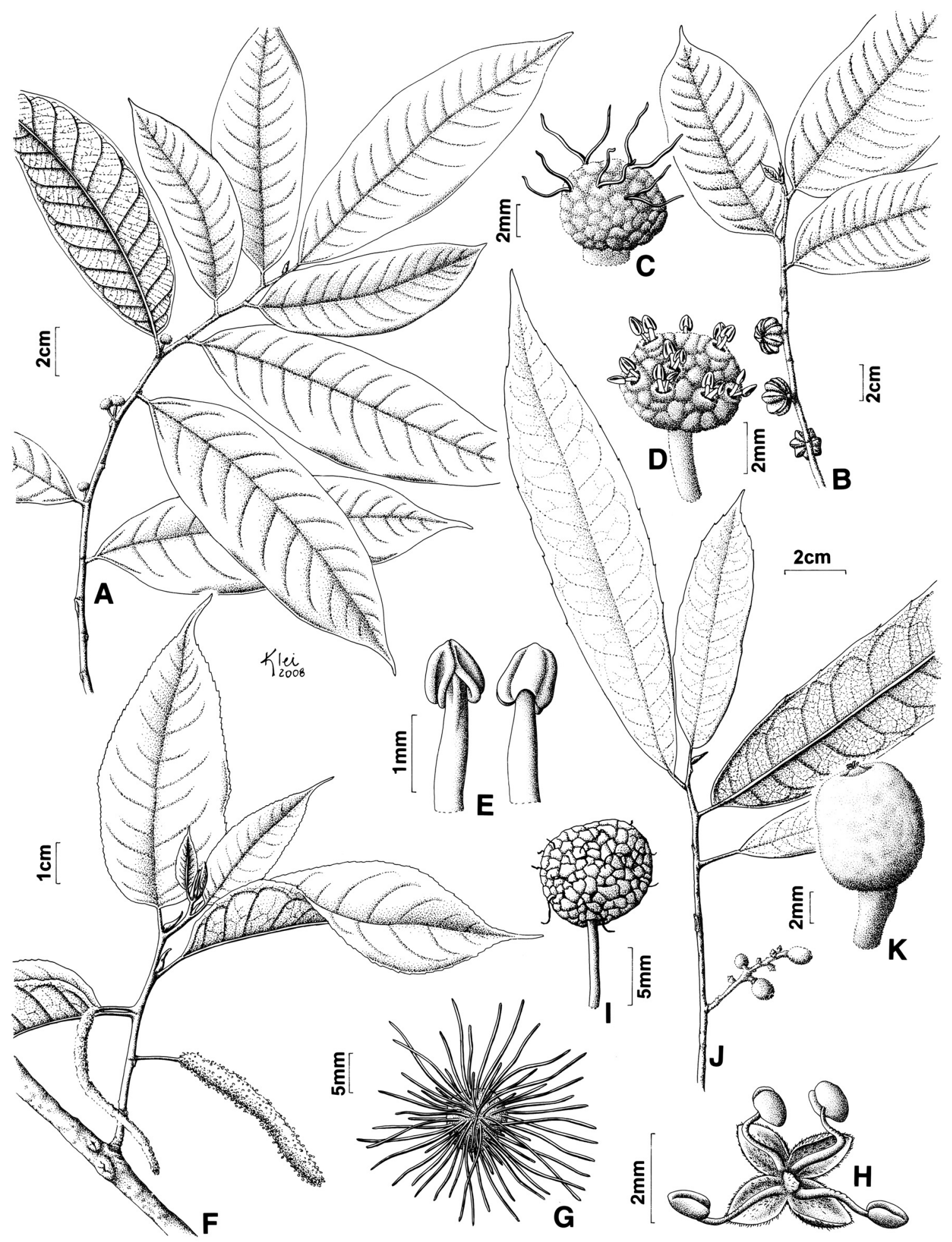

Fig. 4. A-E. Helicostylis tomentosa. A. Ramo fértil. B. Detalhe de ramo frutífero. C. Inflorescência pistilada. D. Inflorescência estaminada. E. Vista ventral e dorsal do estame. F-I. Maclura tinctoria. F. Ramo fértil. G. Inflorescência pistilada. H. Flor estaminada. I. Infrutescência. J-K. Sorocea guilleminiana. J. Ramo fértil. K. Fruto. A, D e E: Santos \& Borges 538. B: Santos \& Serafim 336. C: Santos \& Borges 540. F e H: Santos \& Martins 177. G e I: Santos \& Borges 204. J e K: Santos \& Borges 541. 


\section{Agradecimentos}

Aos curadores dos herbários visitados (BHCB, ESA, HRCB, MBM, OUPR, R, RB, SP, SPF, UEC) pelos empréstimos de espécimes para esse projeto. Ao Prof. Sergio Romaniuc pelas valiosas discussões realizadas durante o mestrado do primeiro autor. Ao CNPq pelas bolsas de mestrado e de produtividade concedidas ao primeiro e segundo autor, respectivamente, e pelo longo apoio ao projeto florístico da Serra do Cipó. Ao CEPEMA-USP/FUSP pela bolsa de pesquisa concedida ao primeiro autor e ao Klei Sousa pelas ilustrações

\section{Referências}

BATTILANI, J.L., SANTIAGO, E.F. \& SOUZA, A.L.T. 2006 Morfologia de frutos, sementes e desenvolvimento de plântulas e plantas jovens de Maclura tinctoria (L.) D. Don. Ex Steud. (Moraceae). Acta Bot. Bras. 20(3): 581-589.

BERG, C.C., AVILA, M.V. \& KOOY, F. 1984. Ficus species of Brazilian Amazonia and the Guianas. Acta Amaz. Supl. 14(1/2): 159-194.

BERG, C.C., AKKERMANS, R.W.A.P. \& HEUSDEN, E.H.van. 1990. Cecropiaceae: Coussapoa and Pouroma, with an introduction to the family. Fl. Neotrop. Monogr. 51: 1-208.

BERG, C.C. \& SIMONIS, J.E. 1981. The Ficus flora of Venezuela: five species complexes discussed and two new species described. Ernstia 6: 1-12.

BERG, C.C. \& SIMONIS, J.E. 2000. Moraceae. In R. Riina (ed.) Flora de Venezuela. Moraceae-Cecropiaceae. Fundación Instituto Botánico de Venezuela. Caracas, p.5-189.

BERG, C.C. \& VILAVICCENCIO, X. 2004. Taxonomic studies on Ficus (Moraceae) in the West Indies, extra-Amazonian Brazil, and Bolivia. Ilicifolia 5: 1-177.

BERG, C.C. 1972. Olmedieae, Brosimeae (Moraceae). Fl. Neotrop. Monogr. n. 7: 1-228.

BERG, C.C. 1978. Cecropiaceae a new family of the Urticales. Taxon 27: $39-44$.

BERG, C.C. 1989. Systematics of Urticales. In P.R. Crane \& S. Blackmore (eds) Evolution, systematics, and fossil history of the Hamamelidae 2, 'Higher'Hamamelidade. Claredon Press. Oxford, p. 193-220.

BERG, C.C. 2001. Moreae, Artocapeae, and Dorstenia (Moraceae) with introductions to the family and Ficus and with additions and corrections to Flora Neotropica Monograph 7. Fl. Neotrop. Monogr. 83: 1-346.

BURGER, W.C., LANJOUW, J. \& BOER, J.G.W. 1962. The genus Sorocea St. Hil. (Moraceae). Acta Bot. Neerl. 11: 428-477.

CARAUTA, J.P.P. 1978. Dorstenia do Brasil e países limítrofes. Rodriguésia 29(44): 53-233.

CARAUTA, J.P.P. 1989. Ficus (Moraceae) no Brasil: conservação e taxonomia. Albertoa 2: 1-365.

CARAUTA, J.P.P. 1993. Moraceae da Reserva Florestal Estadual da Vista Chinesa, Rio de Janeiro. Albertoa 3(19): 193-224.

CARAUTA, J.P.P. 1996. Moráceas do Estado do Rio de Janeiro. Albertoa 4(13): 145-194.
CARAUTA, J.P.P. \& DIAZ, B.E. 2002a. Figueiras no Brasil. Editora UFRJ. Rio de Janeiro.

CARAUTA, J.P.P., ALBUQUERQUE, J.M., CASTRO, R.M. 2002. Dorstenia (Moraceae): notas complementares V. Albertoa ser. Urticineae (Urticales) 8: 53-56.

CARAUTA, J.P.P., ROMANIUC-NETO, S. \& SASTRE, C. 1996. Índice das espécies de Moráceas do Brasil. Albertoa 4(7): 77-96.

CASTRO, R.M. 2006. Flora da Bahia - Moraceae. Dissertação de Mestrado. Universidade Estadual de Feira de Santana. Feira de Santana, Bahia.

CASTRO, R.M. \& RAPINI, A. 2006. Four new species of Moraceae from Bahia, Brazil. Neodiversity 1: 13-20.

CORNER, E.J.H. 1962. The classification of Moraceae. Gard. Bull. Singapure 19(2): 187-252.

CRESTANA, M.S.M., FORRETTI, A.R., TOLEDO FILHO, D.V., ÁRBOCZ, G.F., SCHMIDT, H.A.P. \& GUARDIA, J.F.C. (orgs.) 2006. Florestas - Sistemas de recuperação com essências nativas, produção de mudas e legislações. Ed. 2. CATI. Campinas.

DATWYLER, S.L. \& WEIBLEN, G..D. 2004. On the origin of the fig: phylogenetic relationships of Moraceae from $n d h \mathrm{~F}$ sequences. Amer. J. Bot. 91(5): 767-777.

DURIGAN, G. \& NOGUEIRA, J.C.B. 1990. Recomposição de matas ciliares. Instituto Florestal. IF Série Registros 4. São Paulo.

ENGLER, A. 1907. Syllabus der Pflanzenfamilien. Borntraeger. Berlin. GIULIETTI, A.M., MENEZES, N.L., PIRANI, J.R., MEGURO, M. \& WANDERLEY, M.G.L., 1987. Flora da Serra do Cipó, Minas Gerais: caracterização e lista das espécies. Bol. Bot. Univ. São Paulo 9: 1-151.

GRANVILLE, J.J. 1971. Notes sur La biologie florale de quelques espèces du genre Dorstenia (Moracées). Cah. Ortom, sér. Biol. 15: 61-97.

JACOMASSI, E., MOSCHETA, I.S. \& MACHADO, S.R. 2007. Morfoanatomia e histoquímica de Brosimum gaudichaudii Trécul (Moraceae). Acta Bot. Bras. 21(3): 575-597.

KUBITZKI, K., J.G. ROHWER \& BITTRICH, V. (eds.). 1993. The families and genera of vascular plants - II. Flowering plants Dicotyledons, Magnoliid, Hammelid and Caryophyllid families. Springer-Verlag. Berlin, p. 603-611.

LACHANCE, M.A., KLEMENS, J.A., BOWLES, J.M. \& JANZEN, D.H. 2001. The yeast community of sap fluxes of Costa Rican Maclura (Chlorophora) tinctoria and description of two new yeast species, Candida galis and Candida ortonii. FEMS Yeast Research 1: 87-92.

LEITÃO, M.M.N. 1984. Estudo comparativo do sub-gênero Pharmacosycea no Brasil. 1- Ficus obtusiuscula (Miq.) Miq. Bradea 4(6): 31-40.

LITTLE Jr., E.L., WOODBURY, R.O., WADSWORTH, F.H. 1974. Mulberry Family (Moraceae). In LITTLE Jr., E.L., WOODBURY, R.O., WADSWORTH, F.H. (orgs.) Trees of Puerto Rico and the Virgin Islands, vol. 2. U.S. Dep. Agric. Handb. Washington, DC., p.112-125.

LORENZI, H. 2002. Árvores brasileiras: Manual de identificação e cultivo de plantas arbóreas do Brasil, vol. 2. Ed. 2. Instituto Plantarum. Nova Odessa. 
LORENZI, H. \& SOUZA, H.M. 2001. Plantas ornamentais no Brasil: arbustivas, herbáceas e trepadeiras. Ed. 3. Instituto Plantarum. Nova Odessa.

MARTINS, V.L.C., CARAUTA, J.P.P. \& SILVA, I.M. 2007. Moraceae. In J.A.Rizzo (ed.) Flora dos Estados de Goiás e Tocantins Coleção Rizzo, vol. 37. Universidade Federal de Goiás. Goiânia, p. 1-116.

MEGURO, M., PIRANI, J.R., MELLO-SILVA, R. \& CORDEIRO, I. 2007. Composição florística e estrutura das florestas estacionais decíduas sobre calcário a oeste da Cadeia do Espinhaço, Minas Gerais, Brasil. Bol. Bot. Univ. São Paulo 25(2): 147-171.

MELLO-FILHO, L.E. 1963. Introdução ao estudo do gênero Ficus (Moraceae) na Guanabara e arredores. Tese de Doutorado. Universidade do Estado da Guanabara, Rio de Janeiro.

MELLO-FILHO, L.E., NEVES, L.J., CARAUTA, J.P.P. \& DIAZ, B.E. 2001. Morfologia de certos sicônios de Ficus (Moraceae). Albertoa, série Urticineae (Urticales) 3: 18-20.

MENDONÇA-SOUZA, L.R. 2006. Ficus (Moraceae) no Estado de São Paulo. Dissertação de Mestrado, Instituto de Botânica da Secretaria de Estado do Meio Ambiente. São Paulo.

MIQUEL, F.A.W. 1847. Prodromus monographie Ficuum. London J. Bot. 6: 514-588.

MIQUEL, F.A.G. 1853. Artocarpeae. In C.F.P. Martius (ed.). Flora brasiliensis. Frid. Fleischer. Leipzig, vol. 4, pars. 1, p. 79-170.

MIQUEL, F.A.G. 1853. Chlorantaceae, Piperaceae, Urticineae. In C.F.P. Martius (ed.) Flora brasilienis. Frid. Fleischer. Leipzig, vol. 4, pars 1, p. 170-182, tab. 62-63.
OLIVEIRA FILHO, A.T. 2006. Catálogo de árvores nativas de Minas Gerais: Mapeamento e inventário da flora nativa e dos reflorestamentos de Minas Gerais. Editora UFLA. Lavras.

POTT, A. \& POTT, V.J. 1994. Plants of Pantanal. Pantanal Embrapa. Brasília.

RAGUSA NETTO, J. 2002. Fruiting phenology and consumption by birds in Ficus calyptroceras (Miq.) Miq. (Moraceae). Braz. J. Biol. 62(2): 339-346.

ROMANIUC NETO, S. 1996. Sorocea jureiana (Moraceae): a new species from the south of Brazil. Albertoa 4(8): 97-100.

ROMANIUC-NETO, S. 1998. Biodiversité et spéciation dans lê Sud-Est du Brésil et dans le basin du fleuve Paraná: exemple de quelques espèces appartenant à un complexe du genre Sorocea A. St.-Hil. (Moraceae). Compt. Rend. Acad. Sci. Paris, sèr. 3, Sci. Vie. 327: 669-675.

STEVENS, P.F. 2001 (onwards). Angiosperm Phylogeny Website. Version 9, June 2008 [and more or less continuously updated since]. http://www.mobot.org/MOBOT/research/APweb/.

TRÉCUL, A. 1847. Sur la famille des Artocarpées. Ann. Sci. Nat. Bot., Sér. 3, 8: 38-157. 